\title{
Endocytosis of Prion Protein Is Required for ERK1/2 Signaling Induced by Stress-Inducible Protein 1
}

\author{
Fabiana A. Caetano, ${ }^{1 \star}$ Marilene H. Lopes, ${ }^{4 \star}$ Glaucia N. M. Hajj, ${ }^{4 \star}$ Cleiton F. Machado, ${ }^{4}$ Camila Pinto Arantes,, 45 \\ Ana C. Magalhães, ${ }^{1}$ Mônica De Paoli B. Vieira, ${ }^{1}$ Tatiana A. Américo, ${ }^{6}$ Andre R. Massensini, ${ }^{2}$ Suzette A. Priola, ${ }^{7}$ \\ Ina Vorberg, ${ }^{8}$ Marcus V. Gomez, ${ }^{1}$ Rafael Linden, ${ }^{6}$ Vania F. Prado, ${ }^{3}$ Vilma R. Martins, ${ }^{4}$ and Marco A. M. Prado ${ }^{1}$ \\ ${ }^{1}$ Programa de Farmacologia Bioquímica e Molecular, Departamento de Farmacologia, ${ }^{2}$ Departamento de Fisiologia e Biofísica and ${ }^{3}$ Departamento de \\ Bioquímica-Imunologia, Instituto de Ciências Biológicas, Universidade Federal de Minas Gerais, MG 30270-910, Belo Horizonte, Brazil, ${ }^{4}$ Ludwig Institute \\ for Cancer Research-Hospital Alemão Oswaldo Cruz, SP 01323-903, São Paulo, Brazil, ${ }^{5}$ Departamento de Bioquímica, Instituto de Química, Universidade \\ de São Paulo, 05508-900, São Paulo, Brazil, 'Instituto de Biofísica Carlos Chagas Filho, Universidade Federal do Rio de Janeiro, 21949-900, Rio de Janeiro, \\ Brazil, ${ }^{7}$ Laboratory of Persistent Viral Diseases, National Institutes of Health, National Institute of Allergy and Infectious Diseases Rocky Mountain \\ Laboratories, Hamilton, Montana 59840, and ${ }^{8}$ Institute of Virology, Technical University of Munich, 81675 Munich, Germany
}

The secreted cochaperone STI1 triggers activation of protein kinase A (PKA) and ERK1/2 signaling by interacting with the cellular prion $\left(\operatorname{PrP}^{\mathrm{C}}\right)$ at the cell surface, resulting in neuroprotection and increased neuritogenesis. Here, we investigated whether STI1 triggers PrP $\mathrm{C}^{\mathrm{C}}$ trafficking and tested whether this process controls $\operatorname{PrP}^{\mathrm{C}}$-dependent signaling. We found that STI1, but not a STI1 mutant unable to bind $\operatorname{PrP}^{\mathrm{C}}$, induced $\operatorname{PrP}^{\mathrm{C}}$ endocytosis. STI1-induced signaling did not occur in cells devoid of endogenous PrP $\mathrm{P}^{\mathrm{C}}$; however, heterologous expression of $\operatorname{PrP}^{\mathrm{C}}$ reconstituted both PKA and ERK1/2 activation. In contrast, a $\operatorname{PrP}^{\mathrm{C}}$ mutant lacking endocytic activity was unable to promote ERK1/2 activation induced by STI1, whereas it reconstituted PKA activity in the same condition, suggesting a key role of endocytosis in the former process. The activation of ERK1/2 by STI1 was transient and appeared to depend on the interaction of the two proteins at the cell surface or shortly after internalization. Moreover, inhibition of dynamin activity by expression of a dominant-negative mutant caused the accumulation and colocalization of these proteins at the plasma membrane, suggesting that both proteins use a dynamin-dependent internalization pathway. These results show that $\operatorname{PrP}^{\mathrm{C}}$ endocytosis is a necessary step to modulate STI1-dependent ERK1/2 signaling involved in neuritogenesis.

Key words: neurodegeneration; endocytosis; clathrin; raft; prion diseases; flotillin; ERK

\section{Introduction}

Prions are believed to be the causal agent of transmissible spongiform encephalopathies that affect humans and other species. These neurological disorders have in common the corruption of a glycosylphosphatidylinositol (GPI)-anchored host protein known as the prion protein $\left(\mathrm{PrP}^{\mathrm{C}}\right)$. It is widely accepted that a misfolded conformer of $\operatorname{PrP}^{\mathrm{C}}, \operatorname{PrP}^{\mathrm{Sc}}$ (here to denote infectious, $\beta$ sheet-enriched prion), is the major component of the infectious

\footnotetext{
Received 0ct. 22, 2007; accepted May 7, 2008.

This work was supported by Conselho Nacional de Desenvolvimento Científico e Tecnológico (CNPq), Fundação de Amparo à Pesquisa do Estado Minas Gerais-Programa de Apoio a Núcleos de Excelência (PRONEX)-MG, Millennium Institute (MCT/Brazil), Financiadora de Estudos e Projetos, and National Institutes of Health-Fogarty International Center Grants R03 TW007025-01 and R21 TW007800-01 (M.A.M.P., V.F.P., M.V.G.). R.L. and T.A.A. were supported by CNPq, Fundação de Amparo à Pesquisa do Estado do Rio de Janeiro, Coordenação de Aperfeiçoamento de Pessoal de Nível Superior, and PRONEX-RJ. V.R.M. is an International Scholar of the Howard Hughes Medical Institute and received support from Fundação de Amparo à Pesquisa do Estado de São Paulo.

*F.A.C., M.H.L., and G.N.M.H. contributed equally to this work.

Correspondence should be addressed to either of the following: Vilma R. Martins, Ludwig Institute for Cancer Research, Rua Joao Julião 245 1A, SP 01323-903, São Paulo, Brazil, E-mail: vmartins@ludwig.org.br; or Marco A. M. Prado, Departamento de Farmacologia, Instituto de Ciências Biológicas, Universidade Federal de Minas Gerais, Avenida Antonio Carlos 6627, MG 30270-910, Belo Horizonte, Brazil, E-mail: mprado@icb.ufmg.br.

Ana C. Magalhães's, Vania F. Prado's, and Marco A. M. Prado's present address: Robarts Research Institute, University of Western Ontario, London, Ontario, Canada N6A 5K8.

DOI:10.1523/JNEUROSCI.1701-08.2008

Copyright $\odot 2008$ Society for Neuroscience $\quad 0270-6474 / 08 / 286691-12 \$ 15.00 / 0$
}

particle (Prusiner, 1998; Weissmann, 1999). $\mathrm{PrP}^{\mathrm{Sc}}$ interacts with $\operatorname{PrP}^{\mathrm{C}}$ at the cell surface or along the endocytic pathway (Caughey and Raymond, 1991; Caughey and Baron, 2006), but how this interaction imprints novel information to cause disease in the host is a matter of debate. The proposal that $\mathrm{PrP}^{\mathrm{Sc}}$ represents a gain-of-function, toxic conformer has received much attention, whereas the possibility that alterations in physiological functions of $\mathrm{PrP}^{\mathrm{C}}$ contribute to the disease has only recently started to be addressed (Samaia and Brentani, 1998; Martins et al., 2002; Linden et al., 2008).

One of the major difficulties has been to attribute defined physiological roles for $\operatorname{PrP}^{\mathrm{C}}$. Nonetheless, studies in yeast, mammalian cells, and mice models support the hypothesis that $\operatorname{PrP}^{\mathrm{C}}$ plays a major role in neuroprotection (for review, see Westergard et al., 2007). Recent data pointed at specific domains of the molecule that are essential for $\operatorname{PrP}^{\mathrm{C}}$-mediated protection. Mice expressing a $\mathrm{PrP}^{\mathrm{C}}$ mutant without amino acids 105-125 (hydrophobic domain) in a $\operatorname{PrP}^{\mathrm{C}}$-null background spontaneously developed severe neurodegenerative illness that was lethal within 1 week after birth (Li et al., 2007). Additionally, the presence of a $\mathrm{PrP}^{\mathrm{C}}$ variant lacking residues $94-134$ induced a rapidly progressive lethal phenotype with extensive central and peripheral myelin degeneration (Baumann et al., 2007). 
We have demonstrated that the $\operatorname{PrP}^{\mathrm{C}}$ domain, which includes amino acids 113-128, is the binding site for the cochaperone stress-inducible phosphoprotein 1 (STI1). $\operatorname{PrP}^{\mathrm{C}}$ engagement with STI1 rescued retinal and hippocampal neurons from programmed cell death through activation of protein kinase A (PKA) (Chiarini et al., 2002; Zanata et al., 2002; Lopes et al., 2005). Additionally, $\operatorname{PrP}^{\mathrm{C}}$-STI1 binding also induced the differentiation of hippocampal neurons by ERK1/2 activation (Lopes et al., 2005). Understanding the fate of both STI1 and $\operatorname{PrP}^{\mathrm{C}}$ after their association at the cell surface may help clarify the mechanisms associated with the neurotrophic roles of $\mathrm{PrP}^{\mathrm{C}}$, and its possible bearing on loss-of-function components of prion diseases.

To address these questions, we initially tested whether STI1 alters $\operatorname{PrP}^{\mathrm{C}}$ trafficking. Indeed, we found that interaction of these proteins at the cell surface triggered $\operatorname{PrP}^{\mathrm{C}}$ endocytosis. Remarkably, the transient ERK1/2 activity induced by $\operatorname{PrP}^{\mathrm{C}}$ interaction with either recombinant STI1 or endogenous STI1 secreted by astrocytes depended on $\operatorname{PrP}^{\mathrm{C}}$ endocytosis, whereas activation of PKA was not affected when $\operatorname{PrP}^{C}$ trafficking was impaired. STI1 localized in $\operatorname{PrP}^{\mathrm{C}}$-positive organelles only in the initial periods of internalization, suggesting that signaling is triggered by the interaction of these two proteins at the cell surface or shortly after. These data show for the first time that ligand-induced endocytosis of $\mathrm{PrP}^{\mathrm{C}}$ is important for cellular signaling.

\section{Materials and Methods \\ Animals \\ The Principles of Laboratory Animal Care (National Institutes of Health publication number 85-23, 1996) was strictly followed in all experiments. ZrchI Prnp ${ }^{0 / 0}$ mice were provided by Dr. C. Weissmann (Scripps Florida, Jupiter, FL) (Bueler et al., 1992), and the wild-type control mice (ZrchI Prnp ${ }^{+/+}$) were generated by crossing F1 descendants from 129/SV and C57BL/6J mating.}

\section{Cell culture}

SN56 cells are derived from mouse septum neurons (Hammond et al., 1990) and were cultured as described previously (Santos et al., 2001).

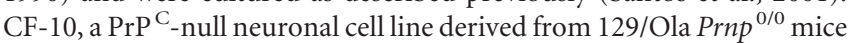
(Manson et al., 1994) and positive for the neuroectodermal stem cell marker nestin (I. Vorberg and S. A. Priola, unpublished observation), was used for reconstitution of $\operatorname{PrP}^{\mathrm{C}}$ signaling. CF-10 cells were cultured in OptiMEM (Invitrogen) containing glutamine ( $2 \mathrm{~mm}$; Invitrogen), penicillin (100 IU), and streptomycin $(100 \mu \mathrm{g} / \mathrm{ml}$; Invitrogen) supplemented with $10 \%$ fetal bovine serum.

Primary hippocampal cultures were obtained from embryonic day 17 brains of either wild-type $\left(\operatorname{Prnp}^{+/+}\right)$or $\operatorname{Prn} p^{0 / 0}$ mice (Bueler et al., 1992). The hippocampus was aseptically dissected in HBSS (Invitrogen) and treated with trypsin $(0.06 \%)$ in HBSS for $20 \mathrm{~min}$ at $37^{\circ} \mathrm{C}$. The protease was inactivated with $10 \%$ FCS in Neurobasal medium (Invitrogen) for 5 min. After three washes with HBSS, cells were mechanically dissociated in Neurobasal medium containing B-27 supplement (Invitrogen), glutamine (2 mM; Invitrogen), penicillin (100 IU), and streptomycin (100 $\mu \mathrm{g} / \mathrm{ml}$; Invitrogen $)$. Cells $\left(0.5 \times 10^{6}\right.$ cells $)$ were plated onto coverslips (22 $\mathrm{mm}$ ) coated with $5 \mu \mathrm{g} / \mathrm{ml}$ poly-L-lysine (Sigma).

\section{Plasmids}

The GFP-PrP ${ }^{\mathrm{C}}$ vector, GFP-Rab5, dynamin I, the dominant-negative dynamin I K44A, and GFP-Rab7 mutant plasmids have been described previously (Lee et al., 2001; Santos et al., 2001; Barbosa et al., 2002; Magalhães et al., 2002, 2005; Ribeiro et al., 2005). Flotillin1-green fluorescent protein (GFP) and caveolin-1-GFP were kindly provided by Dr. B. J. Nichols (MRC Laboratory of Molecular Biology, Cambridge, UK). The 3F4-tagged plasmids, PrP3F4, and the N-PrP3F4 (N-terminally mutated, altered from ${ }^{23} \mathrm{KKRPKP}^{28}$ to ${ }^{23} \mathrm{KQHPSP}^{28}$ ) (Sunyach et al., 2003) were kindly provided by R. Morris (Wolfson Centre for Age Related Diseases, Guy's Hospital Campus, King's College, London, UK). It is important to note that in the N-PrP3F4 mutant, a serine is present at the position 27 and not histidine as published previously (Sunyach et al., 2003) (R. Morris, personal communication).

Transfection of cell lines and isolation of $\operatorname{Pr}^{C}$-expressing cells SN56 cells were plated on coverslips for $2 \mathrm{~d}$ and transfected using the liposome-mediated method (Effectene; Qiagen) according to the manufacturer's instruction using a 1:10 ratio of DNA to Effectene. After $6 \mathrm{~h}$ of transfection, cells were differentiated in serum-free medium supplemented with $1 \mathrm{~mm}$ dibutyryl-cAMP (Sigma) for 2 or $3 \mathrm{~d}$ with medium changes every day. In cotransfection experiments, a total of 3-5 $\mu \mathrm{g}$ of DNA was used with a plasmid ratio of 1:4 of clathrin-GFP, flotillin1GFP, and caveolin-1-GFP and a ratio of 1:2 for GFP-PrP ${ }^{\mathrm{C}}$ and dynamin I or dynamin I K44A.

CF-10 cells were transfected with either 3F4-tagged $\operatorname{PrP}^{\mathrm{C}}(\operatorname{PrP} 3 \mathrm{~F} 4)$ or the mutant $\operatorname{PrP}^{\mathrm{C}} \mathrm{N}-\mathrm{PrP} 3 \mathrm{~F} 4$ (Sunyach et al., 2003) using a liposomemediated method (Lipofectamine 2000; Invitrogen) according to the manufacturer's instructions using a 1:3 ratio of DNA to lipofectamine. After transfection, the cells were selected with G418 (2 mg/ml; Invitrogen) for $15 \mathrm{~d}$, and resistant cells $\left(10^{7}\right)$ were incubated with mouse anti$\operatorname{PrP}^{\mathrm{C}}$ serum (Zanata et al., 2002) at a 1:100 dilution for $1 \mathrm{~h}$ at $4^{\circ} \mathrm{C}$. As a negative control, the cells were incubated with preimmune serum. After three washes with PBS, cells were incubated with anti-mouse IgG R-phycoerythrin conjugated at a 1:200 dilution for $1 \mathrm{~h}$ at $4^{\circ} \mathrm{C}$. Cell sorting was performed using a FACSCalibur flow cytometer (BD Biosciences). Fluorescence was measured using a $488 \mathrm{~nm}$ argon laser and FL2-H channel (red fluorescence, 585/42 nm), and data acquisition from 10,000 events was analyzed using CellQuest software (BD Biosciences). Sorting was accomplished using logical gating of the cells in the forward scatter (FSC) versus side scatter and the FSC versus FL2 dot plots. Only events that entered a gate consisting of both cell regions were sorted.

\section{Alexa Fluor 594, 568, or 488 protein labeling}

Recombinant STI1 [wild type or deleted in residues 230-245 $\left.\left(\mathrm{STI}_{\Delta 230-245}\right)\right]$ was expressed and purified as described previously (Zanata et al., 2002). STI1 labeling was performed using an Alexa Fluor 594 (AF594), Alexa Fluor 568 (AF568), or Alexa Fluor 488 (AF488) labeling kit (Invitrogen). Briefly, STI1 ( $2 \mathrm{mg} / \mathrm{ml})$ diluted in PBS containing $100 \mathrm{~mm}$ sodium bicarbonate was labeled with the reactive dye for $1 \mathrm{~h}$ at room temperature, and free dye was separated from the labeled protein by size exclusion chromatography using a PD-10 column (GE Healthcare). Protein concentration was determined with Bradford reagent (Bio-Rad).

\section{Protein detection}

Fluorescent-labeled proteins (STI1 and STI1 ${ }_{\Delta 230-245} ; 2 \mu \mathrm{g}$ ) were submitted to $10 \%$ SDS-PAGE. To visualize labeled proteins, the gel was irradiated with ultraviolet light, and images were acquired using a UV transilluminator MultiDoc-It-Digital Imaging System (Bioimaging Systems). Alternatively, proteins resolved in 10\% SDS-PAGE were subjected to immunoblotting with polyclonal antibody anti-STI1 $(1: 10,000)$ (Zanata et al., 2002). Rabbit nonimmune-purified IgG was used as the immunoblotting negative control. For detection of $\operatorname{PrP}^{\mathrm{C}}$, cell extracts were prepared by homogenizing the cell pellet in lysis buffer (100 mM Tris, pH 7.4, $150 \mathrm{~mm} \mathrm{NaCl}, 1 \mathrm{~mm}$ EDTA, $1 \%$ Triton X-100, 0.1\% SDS, and 1\% acid deoxycholic) and a protease inhibitor mixture (complete protease inhibitor tablets; Roche Diagnostics) or a protease inhibitor mixture (Sigma) at twice the concentration suggested by the manufacturers. Proteins from cells were resolved in SDS-PAGE, transferred to nitrocellulose or Immobilon-P transfer membranes (Millipore), and incubated with mouse anti-PrP ${ }^{C}$ antibody (Zanata et al., 2002). Staining was revealed by enhanced chemiluminescence (ECL Plus; GE Healthcare) or Super Signal Chemiluminescent Substrate (Pierce).

\section{Fluorescence imaging}

Confocal microscopy was performed using a Bio-Rad MRC 1024 laserscanning confocal system running the Lasersharp 3.0 software coupled to a Zeiss microscope (Axiovert 100 ) with a $100 \times 1.4$ numerical aperture $(\mathrm{NA})$ or $63 \times 1.3 \mathrm{NA}$ oil-immersion lens (Zeiss), a Bio-Rad Radiance 2100 laser-scanning confocal system coupled to a Nikon microscope (TE2000-U), and a Leica SP5 laser-scanning confocal microscope using a 
A

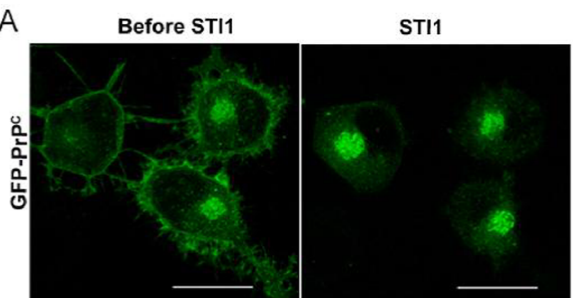

B

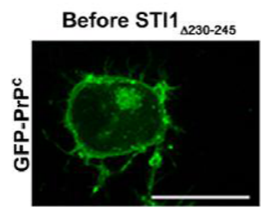

D

C

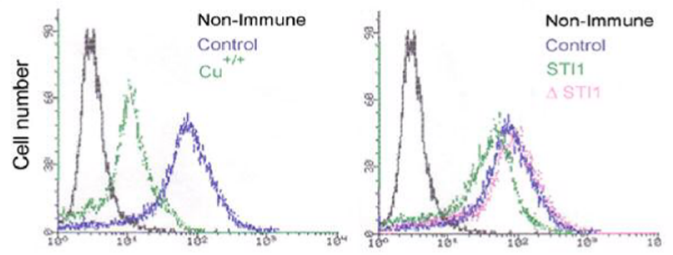

Fluorescence

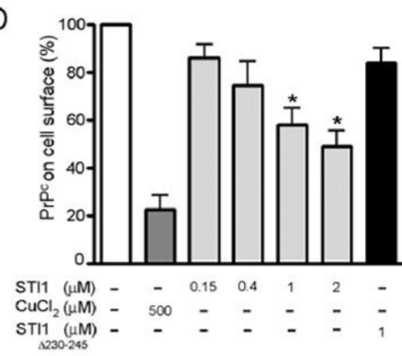

Figure 1. $\boldsymbol{A}, \boldsymbol{B}$, STI1 induces $\operatorname{PrP}^{\mathrm{C}}$ internalization. SN56 cells expressing GFP-PrPC ${ }^{C}$ were treated with $1 \mu \mathrm{M}$ STI1 $(\boldsymbol{A})$ or STI1 ${ }_{\triangle 230-245}(B)$ for $45 \mathrm{~min}$ at $37^{\circ} \mathrm{C}$. The left and right panels show the green fluorescence from GFP-PrP ${ }^{C}$ before and after the incubation with STI1 or STI1 $\Delta_{230-245}$, respectively. $\boldsymbol{A}$ and $\boldsymbol{B}$ represent $Z$ projections acquired before and after the perfusion. Images are representative of nine and five independent experiments with multiple culture plates in which 40 and 12 cells were

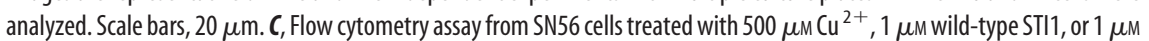
$\mathrm{STI}_{\triangle 230-245}$ for 40 min. Cells were incubated with nonimmune or anti-PrPC mouse serum followed by R-phycoerythrin-labeled anti-mouse lgG. D. The fluorescence for cell-surface $\operatorname{PrP}^{C}$ in untreated cells as described in $C$ was set up to $100 \%$, and the levels of $\mathrm{PrP}^{C}$ cell-surface expression after treatment with the indicated concentrations of $\mathrm{Cu}^{2+}$, STI1, or $\mathrm{STI}_{\triangle 230-245}$ were normalized to untreated cells. The results shown are the mean values of six independent experiments. Error bars represent SEM. ANOVA followed by Tukey's HSD test was used for comparisons. ${ }^{*} p<0.05$.

$63 \times 1.2$ NA water-immersion or a $63 \times 1.4$ oil-immersion lens (Leica). Cells on coverslips were washed and maintained in serum-free medium or Krebs-Ringer-HEPES (KRH) buffer (124 mM NaCl, 4 mM KCl, 1.2 $\mathrm{mm} \mathrm{MgSO}_{4}, 25 \mathrm{~mm}$ HEPES, $10 \mathrm{~mm}$ glucose, and $1 \mathrm{~mm} \mathrm{CaCl}_{2}$ ) during image acquisition. In live cell experiments, a FCS2 chamber and objective heater system (Bioptechs) were used to maintain cells at $37^{\circ} \mathrm{C}$. Image analysis and processing were performed with Lasersharp (Bio-Rad), Confocal Assistant, Adobe Photoshop, Metamorph, Leica Application Suite Advanced Fluorescent Lite, and ImageJ (version 1.24) software.

\section{Internalization of STI1 and $\operatorname{Pr} P^{C}$}

SN56 cells were incubated with $1 \mu \mathrm{M}$ fluorescent STI1 for different periods at $37^{\circ} \mathrm{C}$ in $5 \% \mathrm{CO}_{2}$, washed three times with serum-free medium, and visualized by confocal microscopy. For competition assays, cells were incubated with $10 \mu \mathrm{M} \mathrm{STI1}$ or albumin in DMEM for $1 \mathrm{~h}$ at $4^{\circ} \mathrm{C}$, followed by $1 \mu \mathrm{M}$ fluorescent STI1. The coverslips were washed with serum-free medium and visualized by confocal microscopy.

Cells expressing GFP-PrP ${ }^{\mathrm{C}}$ or coexpressing GFP-PrP ${ }^{\mathrm{C}}$ and dynamin I $\mathrm{K} 44 \mathrm{~A}$ were maintained in a $\mathrm{FCS} 2$ chamber at $37^{\circ} \mathrm{C}$ and perfused with $\mathrm{KRH}$ to obtain the first image. After that, cells were perfused with $1 \mu \mathrm{M}$ fluorescent STI1 or STI1 ${ }_{\Delta 230-245}$, and additional optical sections were acquired each minute for $50 \mathrm{~min}$.

For cell-surface labeling, CF-10 PrP3F4 or N-PrP3F4 cells were treated with STI1 or STI1 ${ }_{\Delta 230-245}$, as described in the figure legends, for $20 \mathrm{~min}$, washed in PBS three times, and fixed in 3.5\% paraformaldehyde without any detergent for $20 \mathrm{~min}$. Cells were incubated simultaneously with monoclonal 3F4 antibodies (1:100; Dako), and after washing with PBS, cells were incubated goat anti-mouse AF488 secondary antibodies (Invitrogen), mounted in coverslips with Hydromount (National Diagnostics), and imaged with the SP5 confocal microscope. In these experiments, nuclei were stained with Syto60Red (Invitrogen).

Biotinylation of cell-surface proteins was performed as described previously (Ribeiro et al., 2005; Lee et al., 2007). Briefly, cells were incubated with STI1 or $500 \mu \mathrm{M} \mathrm{Cu}{ }^{2+}$ for 5 or $10 \mathrm{~min}$, respectively, transferred to ice, washed, and incubated on ice in PBS/CM (PBS supplemented with $1.0 \mathrm{mM} \mathrm{MgCl}_{2}$ and $0.1 \mathrm{mM} \mathrm{CaCl}_{2}$ ). Cell-surface proteins were biotinylated with $1 \mathrm{mg} / \mathrm{ml}$ sulfo-NHS-SS-biotin (Pierce) for $1 \mathrm{~h}$ on ice. To

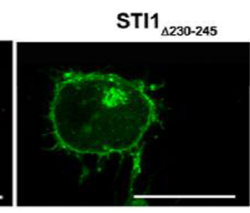

quench the biotinylation reaction, cells were washed and incubated for $30 \mathrm{~min}$ with cold 100 $\mathrm{mM}$ glycine in PBS/CM, followed by three washes with cold $\mathrm{PBS} / \mathrm{CM}$, and proteins were extracted using $10 \mathrm{~mm}$ Tris, $\mathrm{pH}$ 7.8, $0.1 \mathrm{~m} \mathrm{NaCl}, 10 \mathrm{~mm}$ EDTA, $0.5 \%$ Triton X-100, and $0.5 \%$ acid deoxycholic. Biotinylated proteins were separated from nonbiotinylated proteins by Neutravidin bead pull-down from equivalent amounts of total cellular protein $(800 \mu \mathrm{g})$ from each sample. The biotinylated proteins were subjected to SDSPAGE, followed by electroblotting onto polyvinylidene fluoride membranes, and revealed using a mouse anti- $\operatorname{PrP}^{\mathrm{C}}$ antibody (Zanata et al., 2002). For quantification, the major glycosylated band of $\operatorname{PrP}^{\mathrm{C}}$ in nonsaturated blots was analyzed using ImageQuant TL and normalized by the expression of $\mathrm{PrP}^{\mathrm{C}}$ in the lysates.

\section{Labeling of organelles}

Labeling of endosomes was performed by incubating cells with $40 \mu \mathrm{g} / \mathrm{ml}$ AF488-labeled transferrin (Invitrogen) at $37^{\circ} \mathrm{C}$ in $5 \% \mathrm{CO}_{2}$ for $40 \mathrm{~min}$. After incubation, cells were washed three times with PBS and fixed with 3\% paraformaldehyde in PBS for 20 min for posterior imaging. Labeling of late endosomes/lysosomes was done by incubating cells with $1 \mu \mathrm{M}$ Lysosensor Green DND-189 (Invitrogen) at $37^{\circ} \mathrm{C}$ in $5 \% \mathrm{CO}_{2}$ for $1 \mathrm{~h}$, and cells were washed as described above and imaged.

\section{Quantification of fluorescence}

The effect of dynamin K44A expression on STI1 internalization was evaluated using the ImageJ software or MetaMorph. The total fluorescence inside cells after a $40 \mathrm{~min}$ incubation with STI1-AF568 was quantified. Images were thresholded, and the total fluorescence was detected automatically and independently by the software. The results were expressed as the mean of total fluorescence per cell. For colocalization indices, cells were analyzed using MetaMorph, by independently counting fluorescent objects (vesicles) and analyzing the percentage of colocalization independently by the software.

\section{Conditioned medium from astrocytes}

Primary mouse astrocyte cultures were obtained as described previously (Lima et al., 2007). After reaching confluence, cells were maintained in DMEM without serum for $48 \mathrm{~h}$. The conditioned medium (CM) was collected, centrifuged for $10 \mathrm{~min}$ to remove cellular debris, and filtered in $0.2 \mu \mathrm{m}$ membranes. CM (total volume of $30 \mathrm{ml}$ ) was concentrated to a final volume of $150 \mu \mathrm{l}(200 \times)$ in Minicon Static concentrator B12 (Millipore). A total of $30 \mu \mathrm{l}$ of the $200 \times$ concentrated CM was used to measure STI1 concentration. Alternatively, $50 \mu \mathrm{l}$ of the $200 \times$ concentrated CM was immunodepleted of STI1 using a rabbit anti-STI1 antibody (IgG, $4 \mu \mathrm{g} / \mathrm{ml}$ ) overnight at $4^{\circ} \mathrm{C}$ (Lima et al., 2007), mixed with protein A-Sepharose for $2 \mathrm{~h}$ at $4^{\circ} \mathrm{C}$, and centrifuged. The pellets (washed three times) and supernatants were analyzed for the presence of STI1.

\section{Kinase assays}

P44/42 extracellular signal-regulated kinase phosphorylation. Phosphorylation assays were performed using the PhosphoPlus p44-42 extracellular signal-regulated kinase (ERK) (Thr202/Tyr204) antibody kit (Cell Signaling Technology) according to the manufacturer's instructions. Briefly, CF-10 cell lines $\left(5 \times 10^{4}\right.$ cells, serum starved for $48 \mathrm{~h}$ with medium change every $24 \mathrm{~h})$ and hippocampal primary culture $\left(10^{6}\right.$ cells $)$ were stimulated or not with recombinant STI1 $(0.5 \mu \mathrm{M})$ or $50 \mu \mathrm{l}$ of the $200 \times$ concentrated CM to a final volume of $1 \mathrm{ml}(5 \mathrm{~nm} \mathrm{STI} 1)$, rinsed once with ice-cold PBS, and lysed in Laemmli buffer. Cell extracts were subject to SDS-PAGE, followed by immunoblotting with anti-phospho-ERK1/2 and anti-ERK1/2 antibodies (Cell Signaling Technology). The bands obtained after $\mathrm{x}$-ray film exposure to the membranes were analyzed by densitometric scanning and quantified using the Scion Image software. 
A
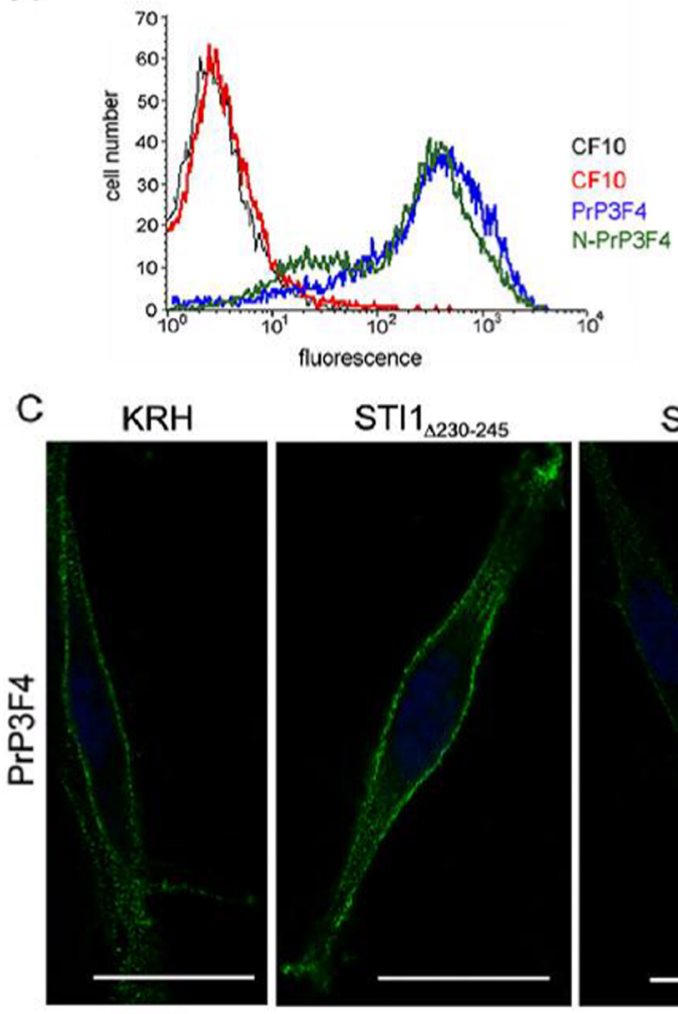

E

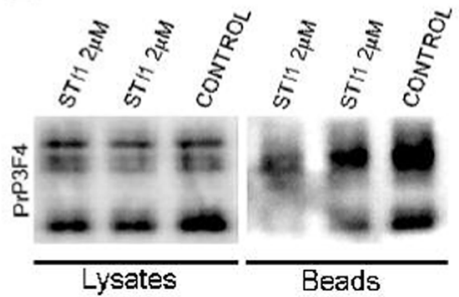

STI1

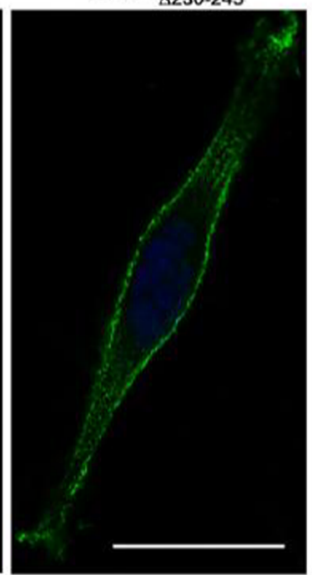

B
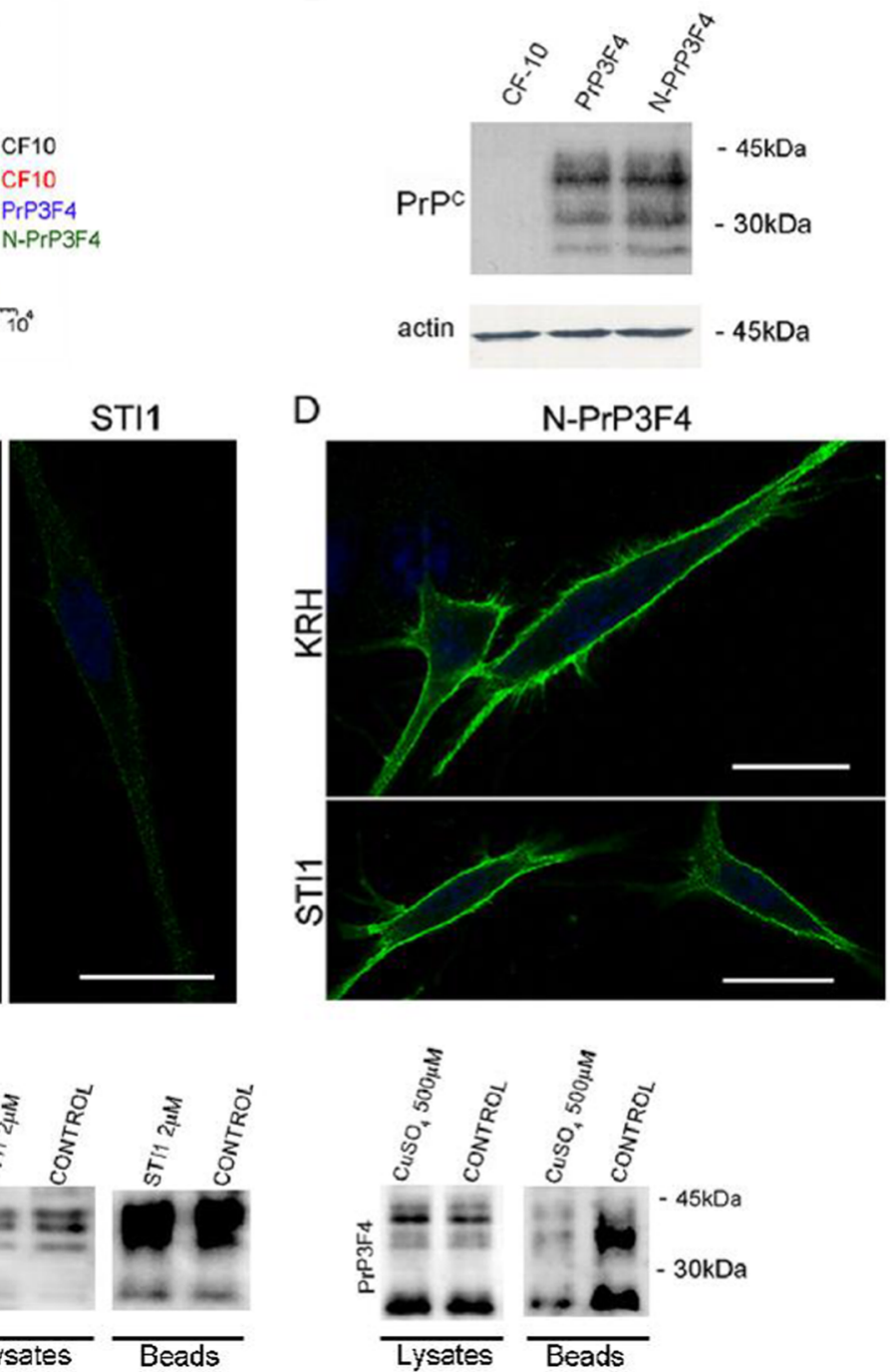

Figure 2. Internalization of $\operatorname{PrP}^{C}$ is dependent of the N-terminal basic motif. The PrP ${ }^{C}$-null cell line $\left(F-10\right.$ was transfected with an expression vector encoding wild-type $\operatorname{PrP}{ }^{C}$ ( $\left.P r P 3 F 4\right)$ or a mutated $\operatorname{PrP}^{\mathrm{C}}$ (N-PrP3F4) protein, the internalization of which is impaired, and stably transfected cells were sorted. $\boldsymbol{A}$, Flow cytometry of nonpermeabilized cells detected using anti-PrPC antibodies (except in CF-10 cells, black lines that were incubated only with secondary antibodies). $\boldsymbol{B}$, Western blot assays using anti-PrP ${ }^{C}$ antibodies show similar expression of ectopic proteins. C, PrP3F4 cells were kept in KRH or treated with $2 \mu \mathrm{m} S \mathrm{STI}_{\triangle 230-245}$ (second column) or STI1 (third column) for $20 \mathrm{~min}$ at $37^{\circ} \mathrm{C}$. After treatment, cells were fixed and immunostained for cell-surface PrPC using the $3 F 4$ antibody. D, As in C, the N-PrP3F4 mutant cells were treated with $2 \mu \mathrm{m}$ STI1 for 20 min at $37^{\circ} \mathrm{C}$. Scale bars, $20 \mu \mathrm{m}$. $\boldsymbol{E}$, PrP3F4- or N-PrP3F4-expressing cells were treated with STI1 or KRH for 5 min and iced. Cell-surface PrPC after these treatments was detected by biotinylation of cell-surface proteins. Biotinylated proteins were isolated using Neutravidin beads, subjected to SDS-PAGE, and immunobloted using a mouse anti-PrPC antibody. The lysates represent the expression of PrP3F4 or N-PrP3F4 proteins, and beads represent biotinylated cell-surface PrP C after treatment with STI1 or KRH (control). Note that STI1 decreased the amount of PrP3F4 in the membrane in the two lanes (duplicates) labeled STI1 compared with control, whereas N-PrP3F4 was not decreased. Treatment with $500 \mu \mathrm{m} \mathrm{CuSO} \mathrm{H}_{4}$ for 10 min was used to test for efficient detection PrP C ${ }^{C}$ ell-surface sequestration. The blots are representative of six or seven experiments, respectively.

PKA activation. Primary hippocampal neurons $\left(10^{6}\right.$ cells $)$, the SN56 cell line $\left(10^{6}\right.$ cells, medium starved $\left.24 \mathrm{~h}\right)$, or the CF- 10 cell line $\left(10^{5}\right.$ cells, serum starved for $48 \mathrm{~h}$ with medium change every $24 \mathrm{~h}$ ) were preincubated with $100 \mu \mathrm{M}$ IBMX (Sigma) for $1 \mathrm{~h}$ at $37^{\circ} \mathrm{C}$ and $5 \% \mathrm{CO}_{2}$ and treated with STI1 $(1 \mu \mathrm{M})$ or forskolin $(10 \mu \mathrm{M})$ for $20 \mathrm{~min}$ at $37^{\circ} \mathrm{C}$. The cells were washed with PBS and homogenized with ice-cold extraction buffer $(150$ $\mathrm{mm} \mathrm{NaCl}, 20 \mathrm{~mm} \mathrm{MgCl}_{2}, 1 \%$ Triton X-100, and $25 \mathrm{~mm}$ Tris-HCl, pH 7.4) plus Complete Protease Inhibitor Cocktail (Roche). Cellular debris was removed by centrifugation at $6000 \times g$ for $10 \mathrm{~min}$. The PKA activity was determined by $\gamma\left[\mathrm{P}^{32}\right]$-ATP incorporation to a PKA-specific substrate provided by the PKA assay system kit (Millipore). The reaction was performed according to the manufacturer's instructions.

Flow cytometry assay

SN56 cells were preincubated with blocking solution $(0.5 \%$ BSA in PBS) in the absence or presence of STI1 or copper sulfate for
20 or $40 \mathrm{~min}$ at $37^{\circ} \mathrm{C}$. Cells were washed and incubated with an anti-PrP ${ }^{\mathrm{C}}$ antibody (1:100) (Zanata et al., 2002), followed by anti-mouse IgG conjugated to R-phycoerythrin (1:200; Dako), both for $1 \mathrm{~h}$ at $4^{\circ} \mathrm{C}$. Analyses were performed using a FACSCalibur flow cytometer (BD Biosciences), and data acquisition from 10,000 events was analyzed using CellQuest software (BD Biosciences).

\section{Statistical analysis}

The mean values of at least three independent datasets are shown in the figures; the error bars represent SEM. ANOVA followed by Tukey's honestly significant difference (HSD) test or Kruskal-Wallis one-way ANOVA followed by a Dunn's post hoc test were used for multiple comparisons. For all tests, results were considered statistically significant when $p$ was $<0.05$. 
A

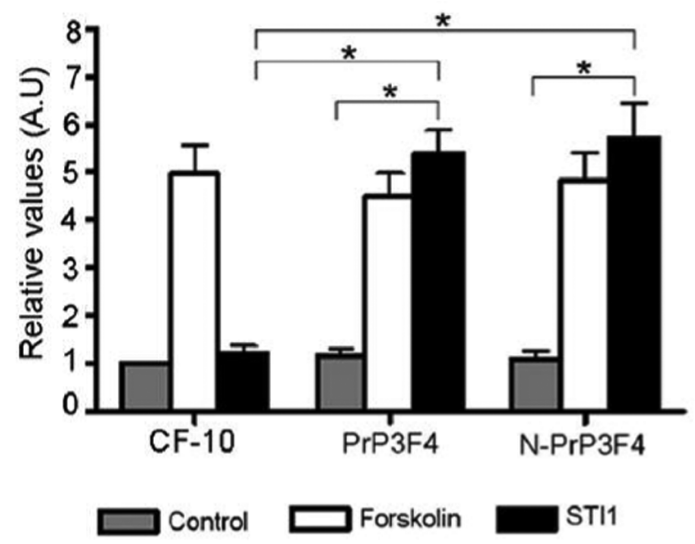

B
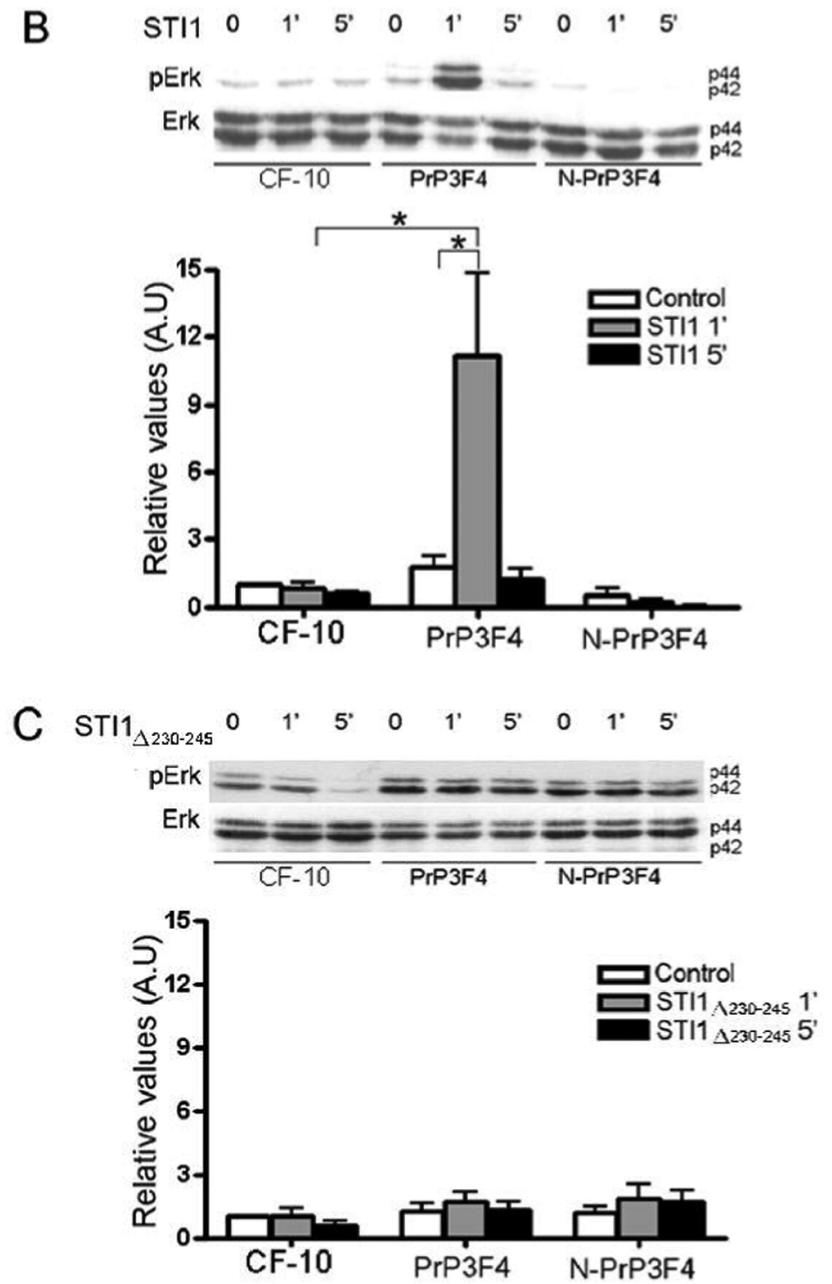

Figure 3. $\operatorname{PrP} \mathrm{C}^{\mathrm{C}}$ endocytic trafficking is necessary for STI-PrP ${ }^{\mathrm{C}}$-dependent ERK $1 / 2$ but not for PKA activation. $\boldsymbol{A}$, Cells were treated with forskolin or $1 \mu \mathrm{m}$ of STI1, and the PKA activity was evaluated. $\boldsymbol{B}$, Cells were treated with $0.5 \mu \mathrm{m}$ STI1 for 1 or $5 \mathrm{~min}$, and ERK1/2 activity (pErk) was analyzed. C, Cells were treated with $0.5 \mu \mathrm{m} \mathrm{STI}_{\triangle 230-245}$ for 1 or $5 \mathrm{~min}$, and ERK1/2 activity was analyzed. The basal activity of $\mathrm{CF}-10$ cells without treatment was normalized to 1 , and the other values are relative to it. The results show the mean values of five $(\boldsymbol{A})$ or four $(\boldsymbol{B}, \boldsymbol{C})$ independent datasets. Error bars represent SEM. ANOVA followed by Tukey's HSD test was used for comparisons. ${ }^{*} p<0.05$. A.U., Arbitrary units.

\section{Results}

STI1 induces $\operatorname{PrP}^{\mathrm{C}}$ internalization

To test whether interaction with STI1 causes any consequence for $\operatorname{PrP}^{\mathrm{C}}$ localization in living cells, we expressed GFP-PrP ${ }^{\mathrm{C}}$ ectopi-
A

B

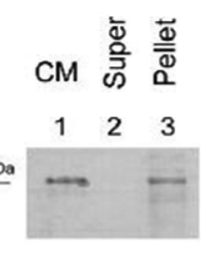

C
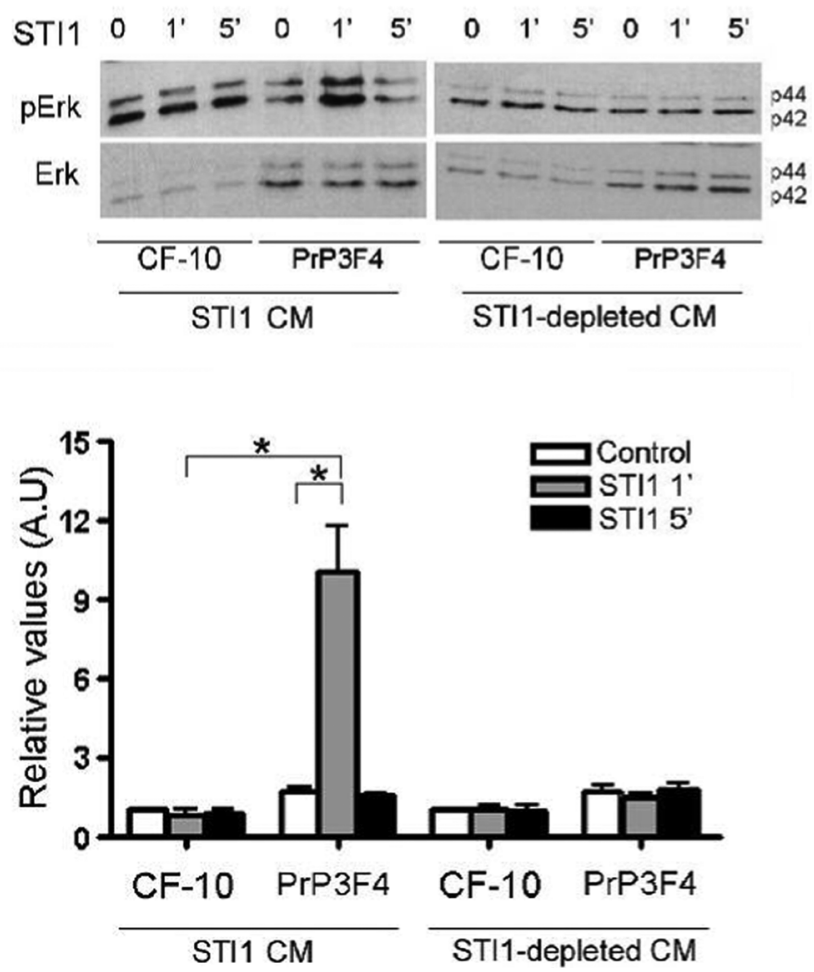

Figure 4. STI1 secreted by astrocytes induces ERK1/2 activation. $\boldsymbol{A}$, Increasing amounts of recombinant STI1 (from 10 to $500 \mathrm{ng}$ ) and $30 \mu$ l of $200 \times$ concentrated CM was loaded onto SDS-PAGE. Immunoblotting was developed with anti-STI1 antibodies. B, STI1 was immunoprecipitated from $150 \mu \mathrm{l}$ of concentrated $\mathrm{CM}$. The supernatant and the pellet were resolved by SDS-PAGE and detected with anti-STI1 antibodies: Iane 1,30 $\mu$ l of concentrated CM; Iane 2, 30 $\mu$ l of immunodepleted concentrated CM; lane 3, $30 \mu$ pellet from immunoprecipitation. $C$, CF-10 or CF-10-expressing PrP3F4 were treated with $50 \mu$ l of concentrated CM (STI1 final concentration of $5 \mathrm{nM}$ ) or immunodepleted concentrated CM for 1 or $5 \mathrm{~min}$, and ERK $1 / 2$ activity was analyzed. The basal activity of CF-10 cells without treatment was normalized to 1 , and the other values are relative to it. The results show the mean values of three independent datasets. Error bars represent SEM. ANOVA followed by Tukey's HSD test was used for comparisons. ${ }^{*} p<$ 0.05. A.U., Arbitrary units.

cally. This fluorescent protein has been previously shown to respond to $\mathrm{Cu}^{2+}$ and to present identical localization as endogenous $\operatorname{PrP}^{\mathrm{C}}$. For these experiments, we used SN56 cells, in which the cellular trafficking of fluorescent $\operatorname{PrP}^{\mathrm{C}}$ and $\operatorname{PrP}^{\text {res }}$ was studied and which have also been shown to be infected by $\operatorname{PrP}^{\text {res }}$ (Lee et al., 2001; Magalhães et al., 2005). Maximum projection images obtained from confocal stacks (data not shown) demonstrated that, as described previously (Lee et al., 2001), GFP-PrP ${ }^{\mathrm{C}}$ is present at the cell surface and in the perinuclear region that represents the Golgi apparatus and endosomes (Magalhães et al., 2002). In control experiments, we reproduced the observation that $\mathrm{Cu}^{2+}$ evokes internalization of GFP-PrP ${ }^{\mathrm{C}}$ (data not shown) (Lee et al., 2001; Magalhães et al., 2002). We then evaluated GFP$\operatorname{PrP}^{\mathrm{C}}$ distribution in SN56 cells after treatment with STI1 or a deletion mutant unable to bind $\operatorname{PrP}^{\mathrm{C}}$, STI1 ${ }_{\Delta 230-245}$ (Lopes et al., 
2005). We noted that a significant fraction of the green fluorescence representing $\mathrm{PrP}^{\mathrm{C}}$ disappeared from the cell surface and accumulated inside cells after STI1 addition (Fig. 1A). Conversely, GFP-PrP ${ }^{\mathrm{C}}$ was not internalized in cells similarly treated with $\mathrm{STI}_{\Delta 230-245}$ (Fig. $1 \mathrm{~B}$ ), indicating the need of STI1-PrP ${ }^{\mathrm{C}}$ interaction for $\operatorname{PrP}^{\mathrm{C}}$ endocytosis.

To test whether endogenous $\operatorname{PrP}^{\mathrm{C}}$ was also internalized in cells in response to STI1 and to quantify this effect, flow cytometry assays were performed. SN56 cells express $\operatorname{PrP}^{\mathrm{C}}$ (Lee et al., 2001; Magalhães et al., 2005; Baron et al., 2006), and treatment with $500 \mu \mathrm{M} \mathrm{Cu}{ }^{2+}$ evoked sequestration of cell-surface $\operatorname{PrP}^{C}$ (Fig. 1C). STI1 also induced internalization of endogenous $\operatorname{PrP}^{C}$ in a dose-dependent manner $\left(\right.$ Fig. $1 D$ ), whereas STI1 ${ }_{\Delta 230-245}$ was unable to promote endocytosis of $\operatorname{PrP}^{\mathrm{C}}$ (Fig. $1 D$ ). The present results show that interaction of STI1 and $\mathrm{PrP}^{\mathrm{C}}$ at the cell surface triggers internalization of $\operatorname{PrP}^{\mathrm{C}}$, albeit at lower levels than copper. Control experiments showed that STI1 interaction with $\mathrm{PrP}^{\mathrm{C}}$ does not shed the latter from the cell surface, because cultures treated with STI1 showed no increase in $\mathrm{PrP}^{\mathrm{C}}$ in $\mathrm{CM}$ (data not shown).

\section{Endocytic trafficking of $\operatorname{PrP}^{\mathrm{C}}$ is required for $\mathrm{STI}-\mathrm{PrP}^{\mathrm{C}}$ - dependent ERK1/2 but not for activation of PKA}

The endocytic trafficking of membrane receptors is important for attenuating ligand-induced signaling, but it can also be critical to trigger and modulate specific signaling pathways as shown, for example, for epidermal growth factor receptors (Vieira et al., 1996). Our previous data showed that PrP ${ }^{\mathrm{C}}-\mathrm{STI} 1$ interaction triggers both PKA and ERK1/2 activation promoting neuronal survival and differentiation, respectively (Chiarini et al., 2002; Lopes et al., 2005). To test for a role of STI1-induced $\mathrm{PrP}^{\mathrm{C}}$ endocytic trafficking on these signaling pathways, we expressed either a mutant $\operatorname{PrP}^{\mathrm{C}}$, the internalization of which is impaired $(\mathrm{N}$ PrP3F4), or its wild-type control (PrP3F4) (Sunyach et al., 2003) in $\mathrm{PrP}^{\mathrm{C}}$-null CF-10 neuronal cells. Transfected cells were selected for similar expression of either wild-type PrP3F4 or N-PrP3F4 mutated $\operatorname{PrP}^{\mathrm{C}}$, as verified by flow cytometry (Fig. $2 A$ ) and Western blot assays (Fig. $2 B$ ). As expected, no endogenous $\operatorname{PrP}^{\mathrm{C}}$ expression was present in untransfected CF-10 cells (note that black and red lines represent CF-10 cells incubated without or with $\operatorname{PrP}^{\mathrm{C}}$ antibodies, respectively) (Fig. $2 A, B$ ).

We initially tested whether in these cells STI1 would also induce endocytosis. Immunofluorescence analysis of cell-surface PrP3F4 indicates that STI1, but not STI1 ${ }_{\Delta 230-245}$, decreased cellsurface immunolabeling for $\operatorname{PrP}^{\mathrm{C}}$ (Fig. 2C). In contrast, in $\mathrm{N}$-PrP3F4-expressing cells, treatment with STI1 did not change cell-surface immunolabeling (Fig. 2D). To complement these experiments and quantify the effect of STI1, we used biotinylation of cell-surface $\operatorname{PrP}^{\mathrm{C}}$ (Fig. $2 \mathrm{E}$ ). In these experiments, we measured the amount of PrP3F4 remaining at the cell surface after the cells were treated with STI1 (Ribeiro et al., 2005; Lee et al., 2007). In control experiments, cells exposed to $\mathrm{Cu}^{2+}$ showed a decrease in cell-surface $\operatorname{PrP}^{\mathrm{C}}(63 \pm 10 \%$ of decrease; mean \pm SEM for seven experiments). Treatment of cells with STI1 for 5 min caused sequestration of $\mathrm{PrP} 3 \mathrm{~F} 4$ with consequent decrease in cell-surface $\operatorname{PrP}^{\mathrm{C}}$ (Fig. 2E) (34 \pm 7\%; mean \pm SEM for six experiments). In contrast, N-PrP3F4 cells treated with STI1 showed no sign of internalization (Fig. $2 E)(2 \pm 2 \%$; mean \pm SEM of four experiments). Thus, the combination of live cell, flow cytometry, immunofluorescence, and biotinylation experiments showed that STI1 was able to induce $\operatorname{PrP}^{\mathrm{C}}$ endocytosis in two distinct neuronal cell lines.

Incubation of PrP-null CF-10 cells with STI1 induced neither
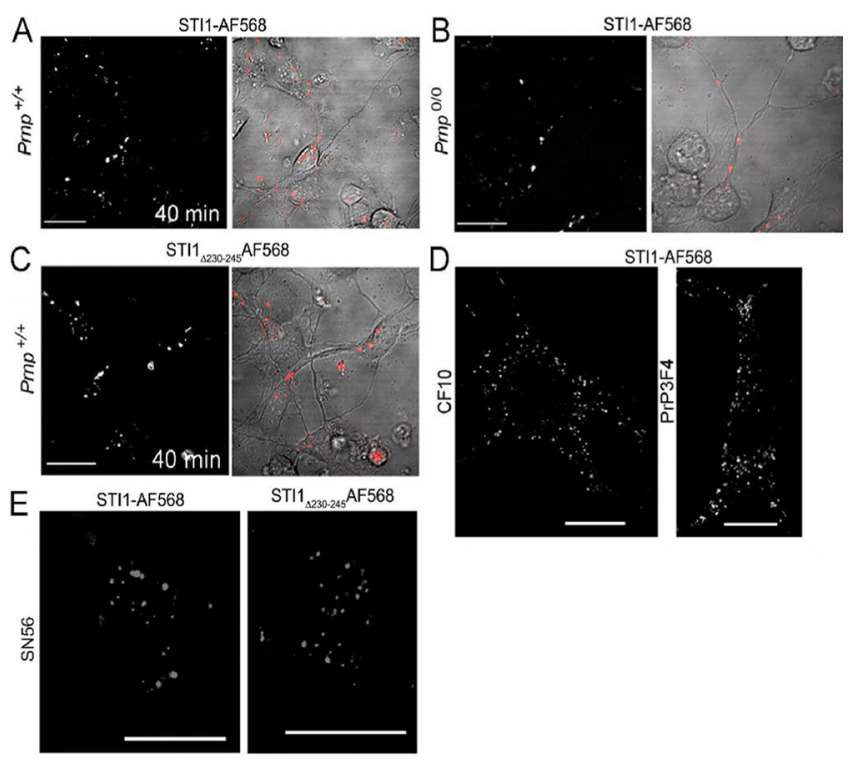

Figure 5. STI1 is internalized independently of $\operatorname{PrP}^{C}$. $\boldsymbol{A}-\boldsymbol{E}$, Wild-type $\operatorname{Prnp}^{+/+}(\boldsymbol{A}, \boldsymbol{C})$; PrPC-null, Prnp ${ }^{0 / 0}$ primary hippocampal neurons $(\boldsymbol{B})$, CF-10 and CF-10 PrP3F4 cells (D); or SN56 cells $(\boldsymbol{E})$ were incubated with $1 \mu \mathrm{M}$ STI1-AF568 or STI ${ }_{\Delta 230-245}-$ AF568, as indicated, for $40 \mathrm{~min}$ at $37^{\circ} \mathrm{C}$. Optical sections of representative cells from at least three independent experiments done in multiple cultures are shown. Scale bars, $20 \mu \mathrm{m}$.

PKA nor ERK1/2 activation, consistent with dependence on $\operatorname{PrP}^{\mathrm{C}}$ for STI1-dependent signaling, although the cells responded to forskolin (Fig. 3A). The expression of either the wild type (PrP3F4) or the internalization defective $\mathrm{PrP}^{\mathrm{C}}(\mathrm{N}-\mathrm{PrP} 3 \mathrm{~F} 4)$ reconstituted STI1-induced PKA activation (Fig. $3 A$ ). In contrast, transient activation of ERK1/2 by STI1 was rescued in CF-10 by wild-type $\operatorname{PrP}^{\mathrm{C}}$, but not by the mutated $\mathrm{PrP}^{\mathrm{C}}$, which lacks internalization signals (Fig. $3 B$ ). The STI1 deletion mutant defective for the $\operatorname{PrP}^{\mathrm{C}}$ binding site, $\mathrm{STI}_{\triangle 230-245}$, is unable to activate either PKA or ERK1/2 signaling in hippocampal neurons (Lopes et al., 2005). In agreement with those observations, CF-10 cells expressing PrP3F4 or N-PrP3F4 presented no activation of ERK1/2 when treated with $\mathrm{STI}_{\Delta 230-245}$ (Fig. $3 C$ ).

Our recent data demonstrated that, similar to chaperones such as Hsp70, STI1 is secreted by astrocytes and presents neurotrophic activity (Lima et al., 2007). To test whether recombinant STI1 may mimic physiologically secreted STI1, we first estimated the amount of STI1 present in CM from astrocytes. Comparison of STI1 in CM with standards containing several concentrations of recombinant STI1 indicates that the amount of STI1 therein is equivalent to $\sim 200 \mathrm{ng}$ of protein (Fig. $4 A$ ), a STI1 final concentration of $33 \mathrm{ng} / \mathrm{ml}$ or $0.5 \mathrm{nM}$ (see Materials and Methods for details). As shown previously (Lima et al., 2007), STI1 from the $\mathrm{CM}$ of astrocytes (Fig. $4 B$, lane 1) can be immunoprecipitated with specific antibodies (Fig. $4 B$, lane 3 ) resulting in a fraction of $\mathrm{CM}$ depleted of this protein (Fig. $4 B$, lane 2). The CM containing STI1 at a final concentration of $5 \mathrm{nM}$ was able to induce ERK1/2 activation in PrP3F4-expressing cells, but not in the PrP-null parent CF-10 cells (Fig. 4C, left). Conversely, STI1-depleted CM did not activate ERK1/2 in any of the cell lines (Fig. 4C, right), suggesting that recombinant STI1 reproduces the effects of secreted protein found in CM derived from astrocytes. It should be noted that 100 times more recombinant STI1 (0.5 $\mu \mathrm{M})$ (Fig. 3B) than astrocyte-secreted STI1 (5 nM) (Fig. $4 C$ ) is necessary to activate ERK1/2. This indicates either that some of the recombinant protein may not be properly folded or that posttranslational 


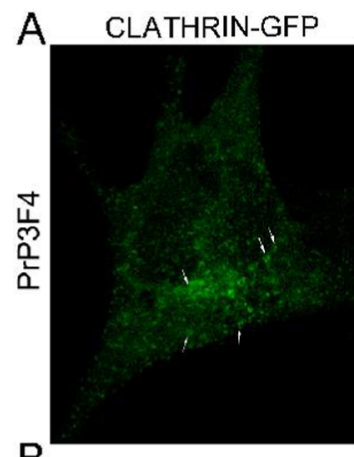

B

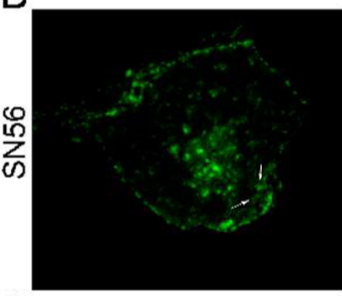

C
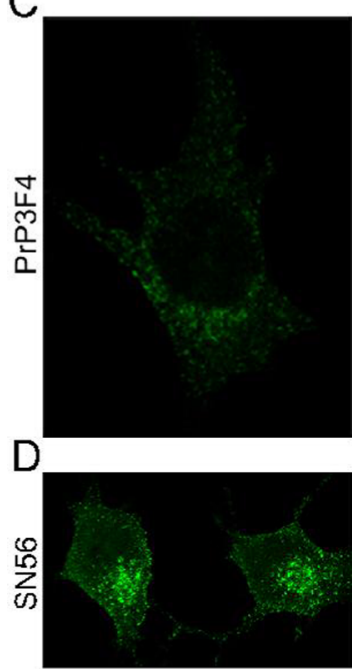

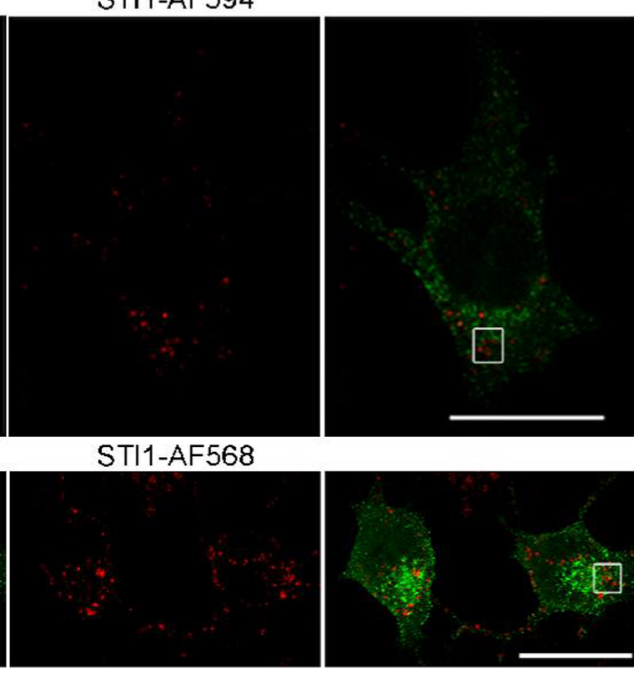

STI1-AF594

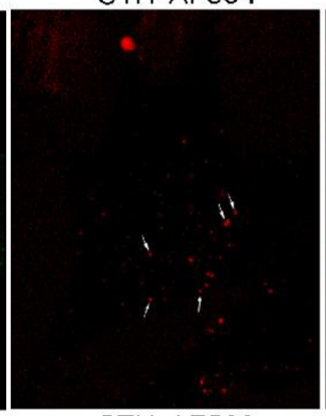

STI1-AF568

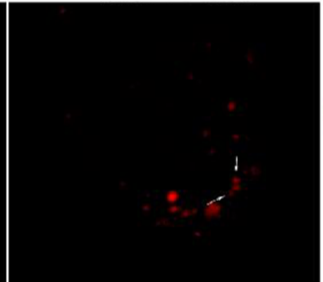

STI1-AF594
MERGE
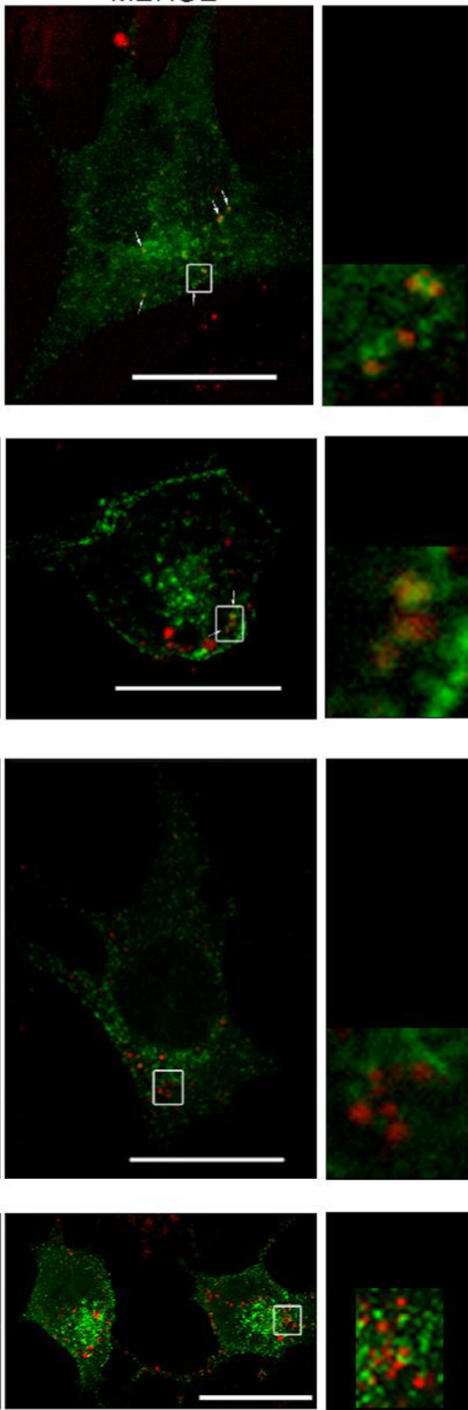

Figure 6. A fraction of internalized STI1 colocalizes with clathrin. PrP3F4 or SN56 cells, as indicated, were transfected with clathrin-GFP and incubated with $1 \mu \mathrm{M}$ STI1-AF594 or STI1-AF568 for various periods of time. $\boldsymbol{A}, \boldsymbol{B}$, Representative images for the first minutes after incubation with STI1. Arrows point to some vesicles where clathrin-GFP and fluorescent STI1 are found. $C$, D, Representative images of transfected cells $20 \mathrm{~min}$ after incubation with STI1. Right panels present a magnified view of the region indicated in the merged images. Arrows indicate some of the colocalization spots. Images are representative of at least 30 cells from several culture dishes on 3 different days. Scale bars, $20 \mu \mathrm{m}$.

modifications in secreted STI1 as well as the presence of coactivators in the CM may contribute for this higher activity compared with the recombinant protein.

\section{STI1 binds to cells in a specific manner and is internalized}

To evaluate STI1 interaction with the cell membrane and its possible dependency on expression of $\mathrm{PrP}^{\mathrm{C}}$ at the cell surface, recombinant STI1 or the deletion mutant unable to bind $\operatorname{PrP}^{\mathrm{C}}$, $\mathrm{STI}_{\Delta 230-245}$ (Lopes et al., 2005), were labeled using AF488, AF568, or AF594. Control experiments showed that labeling STI1 as well as $\mathrm{STI}_{\Delta 230-245}$ did not produce any degradation (supplemental Fig. $1 A, B$, available at www.jneurosci.org as supplemental material) and labeled proteins are able to evoke PKA activity in cultured hippocampal neurons (supplemental Fig. $1 C$, available at www.jneurosci.org as supplemental material) and are therefore functional. Interestingly, STI1-AF568 bound to hippocampal neurons from both wild-type $\left(\operatorname{Prnp}^{+/+}\right)$(Fig. 5A) and $\mathrm{PrP}^{\mathrm{C}}$ -

null $\quad\left(P r n p^{0 / 0}\right) \quad$ (Fig. 5B) mice was internalized. In agreement with these observations, $\mathrm{STI}_{\Delta 230-245}-\mathrm{AF} 568$ was also effectively internalized by wild-type neurons (Fig. 5C). These observations were confirmed in PrP-null CF-10 cells and CF-10 cells expressing PrP3F4 treated with STI1AF488 (Fig. 5D) and also in SN56 cells exposed to STI1-AF568 or STI1 ${ }_{\Delta 230-245^{-}}$ AF568 (Fig. 5E). Therefore, these data suggest that STI1 binds to neuronal cells and is internalized by a $\operatorname{PrP}^{\mathrm{C}}$-independent pathway.

\section{Intracellular localization of internalized STI1}

Although the interaction of STI1 with cells appears to be independent of the presence of $\operatorname{PrP}{ }^{C}$, signaling is strictly dependent on $\operatorname{PrP}^{\mathrm{C}}$ expression, and ERK1/2 activation depends on $\operatorname{PrP}^{\mathrm{C}}$ internalization. Hence, it is possible that engagement of these proteins occurs at the cell surface and continues in intracellular organelles to activate ERK1/2. We investigated this possibility by examining the localization of fluorescent STI1. Confocal images of CF-10 PrP3F4 cells or SN56 cells showed that we could clearly detect internalized fluorescent STI1 after $10 \mathrm{~min}$ of incubation, and additional exposure to medium containing the fluorescent protein lead to increased intracellular accumulation in vesicles (supplemental Fig. $2 A, B$, available at www.jneurosci.org as supplemental material). The interaction of STI1-AF568 with cells and its sequestration in intracellular organelles showed specificity, because no internalization of STI1-Alexa Fluor was detected in experiments done at $4^{\circ} \mathrm{C}$ (data not shown). Moreover, intracellular labeling with fluorescent STI1 was blocked when CF-10 PrP3F4 or SN56 cells (supplemental Fig. 2C,D, available at www. jneurosci.org as supplemental material) were incubated with a 10-fold excess of nonfluorescent protein (STI1) for $1 \mathrm{~h}$, followed by incubation with fluorescent STI.

To test whether fluorescent STI1 is present in the same organelles as $\operatorname{PrP}^{\mathrm{C}}$, we did a series of double-labeling experiments in living cells using GFP-tagged markers of internalization pathways. We chose to study trafficking in living cells to avoid possible fixation artifacts, because GPI-anchored proteins such as $\operatorname{PrP}^{\mathrm{C}}$ may change location after fixation, and we noted that fixed STI1AF568-labeled cells showed a distinct pattern of localization compared with live cells (data not shown). Cells were transfected with clathrin light chain-GFP, which labels both coated pits and clathrin-coated vesicles (Gaidarov et al., 1999). These experiments indicated that STI1 (AF568 or AF594) internalized in cells in the initial period $(<15 \mathrm{~min})$ after incubation showed some colocalization with GFP-clathrin-labeled vesicles both in CF-10 PrP3F4 cells (Fig. 6A) and in SN56 cells (Fig. 6B). In contrast, incubation of STI1-AF568 for 20 or $40 \mathrm{~min}$ (data not shown) with CF-10 PrP3F4 cells (Fig. 6C) or SN56 cells (Fig. 6D) showed 
no colocalization of internalized STI1 (red) with clathrin-coated vesicles (green). Quantification of these colocalization experiments indicated that $41 \pm 8 \%$ of STI1positive vesicles also show clathrin labeling in the initial periods of incubation, but this colocalization decreased to $9 \pm 1 \%$ after cells were exposed to fluorescent STI1 for $>20$ min.

We also investigated a role of raftderived organelles in the trafficking of STI1, by using either caveolin-GFP (Fig. $7 A$ ) or flotillin-GFP (Fig. 7B) in CF-10 PrP3F4 cells and in SN56 cells (Fig. 7C,D). Strikingly, STI1-AF568 (red) partly colocalized with caveolin-1-GFP (green; $36 \pm 8 \%$ of colocalization in CF-10 PrP3F4 cells in the initial periods of incubation), but quantification of colocalization after additional periods of incubation in CF-10 PrP3F4 cells showed decreased colocalization $(15 \pm 2 \%$ after $20 \mathrm{~min}$ incubation). In contrast, STI1AF568 or STI1-AF594 (red) showed extensive colocalization with flotillin1-GFP (green)-labeled vesicles in all time periods examined $(61 \pm 5 \%$ in the initial $15 \mathrm{~min}$ incubation and $68 \pm 2 \%$ after the $20 \mathrm{~min}$ incubation). In SN56 cells, fluorescent STI1 appeared to colocalize extensively with both caveolin- and flotillin-labeled vesicles.

These experiments suggest that internalized STI1 is found predominantly in flotillin organelles at steady state, but a fraction of the protein appears to use clathrincoated vesicles for internalization, a pathway that also serves as the port of entry for $\mathrm{PrP}^{\mathrm{C}}$ (Shyng et al., 1994, 1995; Sunyach et al., 2003; Taylor et al., 2005). To further understand the subcellular localization of STI1, we focused our experiments in SN56 cells, a cell line in which we have previously examined the trafficking of $\operatorname{PrP}^{\mathrm{C}}$ and $\operatorname{PrP}^{\text {res }}$ (Lee et al., 2001; Magalhães et al., 2002, 2005). In agreement with an important role for a raft-derived organelle in the steadystate localization of STI1, we detected almost no colocalization between STI1-AF568 (red) incubated for 20 min (data not shown) or 40 min with AF488-labeled transferrin (green) (Fig. $8 A$ ) or GFP-Rab5 (green) (Fig. $8 B$ ), which are markers of classical early endosomes derived from clathrincoated vesicles.

The above experiments suggest that STI1 may enter cells by two pathways: a smaller fraction of the fluorescent protein seems to use clathrin-mediated endocytosis, but a larger fraction uses a raft-mediated pathway (flotillin and perhaps caveolae in cells that endogenously express caveolin) for internalization. Proteins that are internalized by raft-mediated pathways are able to accumulate in acidic-late endosomal organelles, and flotillin1 (also known as reggie-2) itself is found also in acidic organelles (Stuermer et al., 2004; Pimpinelli et al., 2005). We tested the possibility that STI1 may be located in late endosomes by labeling STI1AF568-treated cells ( $1 \mathrm{~h}$ ) with lysosensor green, a marker of acidic vesicles. Figure $8 C$ shows abundant colocalization between STI1-
AF568 (red) and lysosensor green (green) in SN56 cells. We confirmed that STI1-AF568 was present in late endosomes/lysosomes by expressing GFP-RAB7Q67L, a constitutively active mutant that is preferentially located in these organelles (Bucci et al., 2000; Magalhães et al., 2005). STI1-AF568 (Fig. 8D, red) also colocalized with vesicles labeled with GFP-RAB7Q67L (green). Together, these observations suggest that a larger fraction of fluorescent STI1 accumulates in late endosomes.

\section{STI1 interacts with $\operatorname{PrP}^{\mathrm{C}}$ predominantly at the cell surface} and in early endocytic intermediates

The above experiments suggest only a small fraction of fluorescent STI1 locates to organelles where $\operatorname{PrP}^{\mathrm{C}}$ has been previously found in neurons and neuronal cells (i.e., clathrin-coated vesicles) (Sunyach et al., 2003). To also test in living cells whether both STI and $\operatorname{PrP}^{\mathrm{C}}$ can be found in the same organelles, we used STI1-AF568 and GFP-PrP ${ }^{\mathrm{C}}$. Figure $9 A$ (top) indicates that dur- 
A

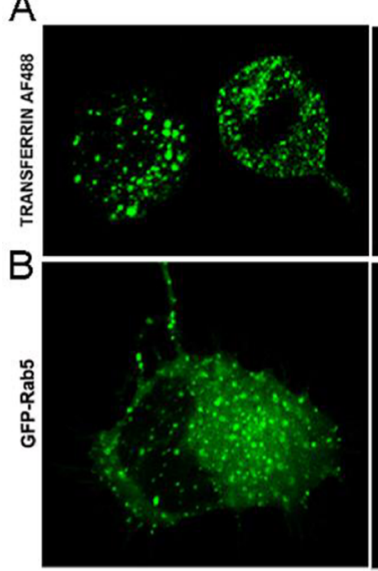

C
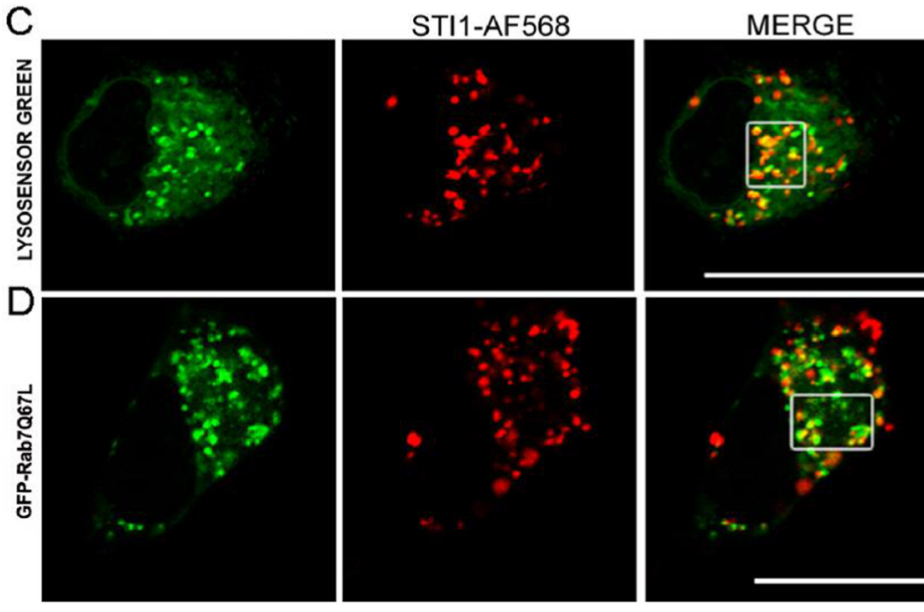

Figure 8. Subcellular localization of STI1. A, SN56 cells were double labeled with STI1-AF568 and transferrin-AF488 for 40 min at $37^{\circ} \mathrm{C}$. B. Cells expressing GFP-Rab5 were incubated with STI1-AF568 for $40 \mathrm{~min}$ at $37^{\circ} \mathrm{C}$. Right panels present a magnified view of the region indicated in the merged images. C, SN56 cells were double labeled with STI1-AF568 and the aciditrophic probe Lysosensor Green (first panel) for $60 \mathrm{~min}$. D. Cells expressing constitutive active mutant GFP-Rab7067L were incubated with STI1-AF568 for $40 \mathrm{~min}$ at $37^{\circ} \mathrm{C}$ (second panel). The merged image shows colocalizations in yellow. The images are representative of three experiments with multiple dishes. At least 30 cells were analyzed in each condition. Scale bars, $20 \mu \mathrm{m}$.

ing the initial periods of incubation ( $14 \mathrm{~min}$ ), a small fraction of STI1 and GFP-PrP ${ }^{\mathrm{C}}$ can be found in similar organelles. Further incubation shows much less colocalization between these two fluorescent proteins (Fig. 9A, bottom).

We have previously demonstrated that GFP-PrP ${ }^{\mathrm{C}}$ localization is affected by a dominant-negative mutant of dynamin I, dynamin K44A (Magalhães et al., 2002). We thus tested whether STI1 internalization would also be altered by dynamin I K44A. In this condition, but not in cells transfected with wild-type dynamin I, STI1-AF568 accumulated at the cell surface in spots (Fig. 9B). Quantification of internalized STI1AF568 fluorescence suggests that cells transfected with the mutant, but not with wild-type dynamin I, sequestered $<5 \%$ of the normal fluorescence found in nontransfected cells, whereas dynamin I had no significant effect in the internalization (Fig. 9C). In addition, we found that cells transfected with GFP-PrP ${ }^{\mathrm{C}}$ and treated with STI1-AF568 showed almost no internalization of $\operatorname{PrP}^{\mathrm{C}}$ when they were cotransfected with dynamin I K44A (Fig. 9D). Additionally, the decrease in endocytosis by this manipulation caused accumulation of STI1AF568 at the cell surface in areas where GFP- $\operatorname{PrP}^{C}$ was also concentrated (Fig. 9D, merge). These results suggest that both proteins use a dynamin-dependent pathway for internaliza-

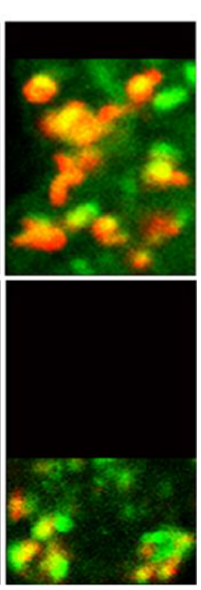

tion and that block of endocytosis causes STI1 to remain bound to $\operatorname{PrP}^{\mathrm{C}}$ at the cell surface.

\section{Discussion}

The present experiments allowed for the first time the direct visualization of the consequences of engagement between STI1 and $\mathrm{PrP}^{\mathrm{C}}$ in living neuronal cells. We revealed that STI1, a $\operatorname{PrP}^{\mathrm{C}}$ ligand that causes cellular signaling with consequences for neuronal survival and differentiation, triggers $\operatorname{PrP}^{\mathrm{C}}$ sequestration and that this is critical for the activation of ERK1/2 but not PKA. We also noted that STI1 is internalized by cells independently of $\mathrm{PrP}^{\mathrm{C}}$ and that although part of STI1 may be internalized together with $\operatorname{PrP}^{\mathrm{C}}$, the two proteins follow distinct downstream intracellular pathways. Finally, signaling by ERK1/2 induced by STI1 is fast and depends on endocytosis of $\operatorname{PrP}^{\mathrm{C}}$, but the interaction of the latter two proteins is likely to be transient once they are both internalized. These results have broad implications for understanding physiological functions of STI1-PrP ${ }^{\mathrm{C}}$ interaction and provide information on how $\operatorname{PrP}^{\mathrm{C}}$ trafficking can be affected by stimuli that promote $\operatorname{PrP}^{\mathrm{C}}$-dependent cell signaling.

Induction of heat shock proteins (HSPs) was initially described as an adaptive response that enhances the survival of cells exposed to environmental insults (Parsell and Lindquist, 1993). The evolutionarily conserved STI1, including its human homolog HSP70/HSP90 organizing protein (Hop), interacts with both HSP70 and HSP90 to facilitate the transfer of substrates, thus playing an important role in proper protein folding and maturation (Hernandez et al., 2002). The HSPs are abundantly expressed in both the cytoplasm and the nucleus (Honore et al., 1992; Lassle et al., 1997); however, growing evidence suggest that some HSPs, in particular HSP90 and HSP70, can be secreted by distinct cells (Eustace and Jay, 2004; Evdonin et al., 2006), including astrocytes (Guzhova et al., 2001; Robinson et al., 2005). Secreted HSP70 has been related to prevention of axotomy-induced death of spinal sensory and motor neurons (Houenou et al., 1996; Tidwell et al., 2004), as well as protection against light damage of photoreceptors (Yu et al., 2001) and enhancement of motoneuron survival in vivo during the period of naturally occurring programmed cell death (Robinson et al., 2005). Thus, HSP70 may function as a neurotrophic factor.

STI1 binds tightly to HSP70 and might be secreted similarly to the latter, although mechanisms of secretion for both proteins are poorly understood. STI1 is secreted from fibrosarcoma cells (Eustace and Jay, 2004), and we have recently found that the protein is also secreted from primary astrocyte cultures and engages $\operatorname{PrP}^{\mathrm{C}}$-dependent neuronal survival (Lima et al., 2007). Moreover, unbiased proteomic analysis of proteins secreted from cells has detected STI1 and HSPs, which are likely secreted by nonconventional pathways (Keller et al., 2008). Indeed, the recombinant 


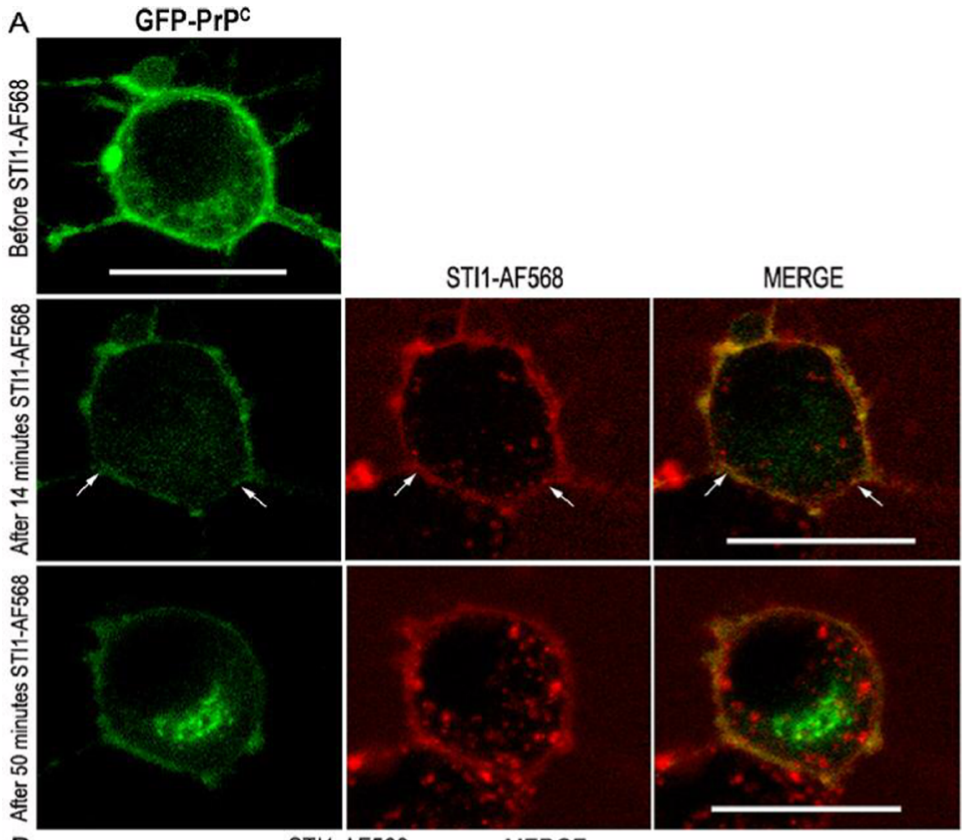

B

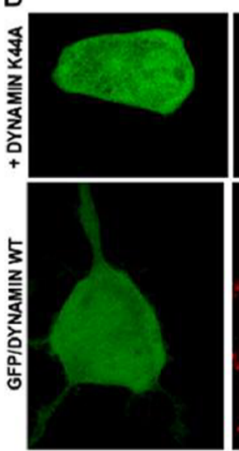

STI1-AF568

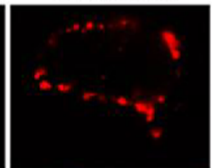

MERGE
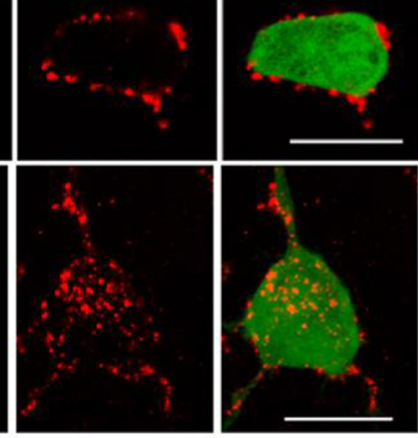

c

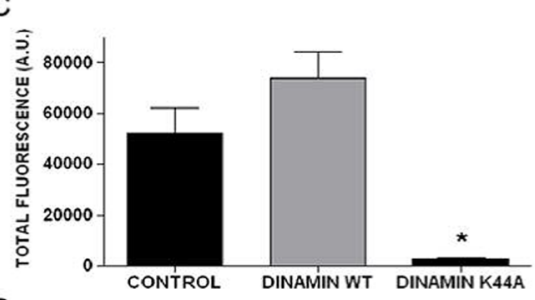

D GFP.PrPC

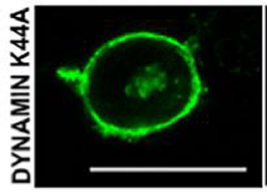

STI1-AF568

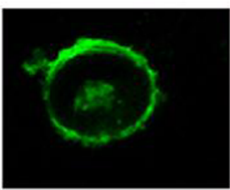

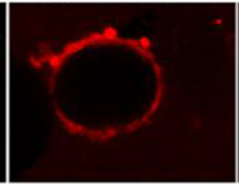

MERGE

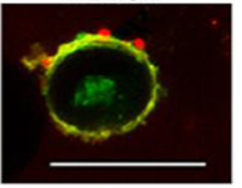

Figure 9. STI1 interacts with $\operatorname{PrP}^{C}$ predominantly at the cell surface. $\boldsymbol{A}$, SN56 cells expressing GFP-PrP ${ }^{C}$ (green) were treated with $1 \mu \mathrm{M}$ STI1-AF568 (red) for distinct periods of time at $37^{\circ} \mathrm{C}$. Images are representative five independent experiments with multiple dishes in which 40 and 12 cells were analyzed. Arrows indicate colocalization spots between GFP-PrPC (green) and STI1 (red) in forming vesicles. $\boldsymbol{B}$, SN56 cells were cotransfected with the constructs GFP and dynamin I K44A (top row) or wild-type (WT) dynamin I (bottom row), and living cells were incubated with $1 \mu \mathrm{M}$ STI1AF568 for $40 \mathrm{~min}$ at $37^{\circ} \mathrm{C}$. C, Quantitative analysis of the STI1-AF568 internalization in the presence of dynamin I K44A. Quantification was done using ImageJ software (control, $n=27$ cells; dynamin I, $n=67$ cells; dynamin I K44A, $n=85$ cells) by scoring every cell for the total values of fluorescence internalized. The results are the mean values of fluorescence per cell from multiple dishes examined on 3 different days. Error bars represent SEM. For these experiments, a KruskalWallis one-way ANOVA was used $(H=120 ; p<0.001)$ followed by a Dunn's post hoc test $\left({ }^{*} p<0.05\right)$. A.U., Arbitrary

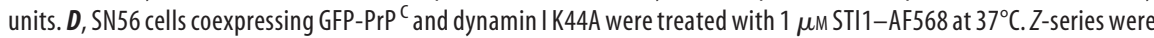
acquired before (GFP-PrPC) and 40 min after (second to fourth panels) treatment with STI1. Images are representative of four independent experiments in which 15 cells were analyzed. Scale bars, $20 \mu \mathrm{m}$.
STI1 used in the current experiments mimics the extracellular secreted STI1 and induced $\operatorname{PrP}^{\mathrm{C}}$-mediated signal transduction, as expected, for a neurotrophic factor.

It is well known that the association between neurotrophic factors and cellsurface receptors induces diverse cellular signals. Some are triggered as the ligand binds to its cognate receptor at the cell surface, and others depend on the internalization of the receptor-ligand complex, a process known as endosomal signal transduction (Gonzalez-Gaitan, 2003). Indeed, evaluation of STI1 intracellular trafficking as well as its role on $\mathrm{PrP}^{\mathrm{C}}$ internalization is of particular interest to understand cell signaling associated with the neurotrophic functions mediated by $\mathrm{PrP}^{\mathrm{C}}$-STI1 interaction. Previously, endocytosis of $\operatorname{PrP}^{\mathrm{C}}$ had been linked to a pro-apoptotic activity mediated by p53 (Sunyach and Checler, 2005), but agonists that activate this process are unknown. Recently, it has been shown that signaling derived from STI1$\mathrm{PrP}^{\mathrm{C}}$ interactions and associated with proliferation of glioblastoma cells depends on general cellular endocytic activity (Americo et al., 2007; Erlich et al., 2007). The present study identifies a mechanism by which $\operatorname{PrP}^{C}$ is internalized and revealed that the endocytosis of $\operatorname{PrP}^{\mathrm{C}}$ is a determinant of STI1-induced cellular signaling. These observations raise the possibility that other events of $\operatorname{PrP}^{\mathrm{C}}$-mediated signaling, such as those elicited by interaction with neural cell adhesion molecule (Santuccione et al., 2005) or antibody crosslinking of $\mathrm{PrP}^{\mathrm{C}}$ (Mouillet-Richard et al., 2000; Stuermer et al., 2004), may also depend on the endocytosis of $\operatorname{PrP}^{\mathrm{C}}$. Recent observations have determined that hemin also interacts with $\operatorname{PrP}^{\mathrm{C}}$ to induce endocytosis (Lee et al., 2007).

In addition to the downregulation of cell signaling (Drake et al., 2006), endocytosis of cell-surface receptors provides for the activity of signaling endosomes (Luttrell et al., 1999; Lefkowitz and Whalen, 2004). Similar to the dichotomous nature of signal transduction by $\beta 2$-adrenergic receptors (Daaka et al., 1998), activation of PKA appears to be independent of the endocytosis of $\mathrm{PrP}^{\mathrm{C}}$, whereas ERK1/2 appears to be highly dependent on $\operatorname{PrP}^{\mathrm{C}}$ internalization. ERK1/2 activation mediated by $\operatorname{PrP}^{\mathrm{C}}-\mathrm{STI} 1$ interaction is known to promote neuronal differentiation (Lopes et al., 2005) and synaptic plasticity (Lopes et al., 2005; Coitinho et al., 2007). Further details on the mechanism of activation of the ERK pathway by STI1 should help clarify this biologically relevant neurotrophic role of $\mathrm{PrP}^{\mathrm{C}}$. 
Our data revealed that extracellular STI1 is also internalized by endocytosis. The site that STI1 binds for its entry in cells has not been identified, but the experiments with the mutant $\mathrm{STI}_{\Delta 230-245}$ and with $\operatorname{Pr} p^{0 / 0}$ neurons conclusively discarded the need of $\mathrm{PrP}^{\mathrm{C}}$ for STI1 entry in cells. Colocalization experiments implicate lipid raft-derived organelles in the intracellular trafficking of STI1. Although we found that a small fraction of fluorescent STI1 colocalizes with clathrin-coated vesicles, STI1 was not found in classical early endosomes in living cells. In contrast, a significant portion of the protein was found in flotillin-derived vesicles. Flotillin1-positive vesicles were proposed to differ from caveolae-derived vesicles (Glebov et al., 2006), but both likely originate from lipid raft-derived regions of the membrane (Harder and Simons, 1997). In agreement with these results, fluorescent STI1 also accumulates in acidic organelles that recruit GFP-Rab7, a marker of late endosomes/lysosomes. In this aspect, internalized STI1 presents a remarkable similarity to fluorescent $\mathrm{PrP}^{\text {res }}$, which was recently shown to be sequestered in SN56 cells in Rab7-positive acidic organelles (Magalhães et al., 2005).

Intracellular trafficking of GPI-anchored proteins is complex, and these proteins can follow distinct pathways depending on the cell type (Fivaz et al., 2002). Despite reports suggesting internalization of $\mathrm{PrP}^{\mathrm{C}}$ via caveolae (Peters et al., 2003), overwhelming evidence favors a model of endocytosis of $\mathrm{PrP}^{\mathrm{C}}$ via clathrincoated vesicles (Shyng et al., 1994; Sunyach et al., 2003; Taylor et al., 2005). Recently, an essential role in the endocytosis of $\operatorname{PrP}^{C}$ has been ascribed to the low-density lipoprotein receptor-like protein (LRP1) (Morris et al., 2006; Taylor and Hooper, 2006; Parkyn et al., 2008), by allowing $\operatorname{PrP}^{\mathrm{C}}$ to enter clathrin-coated vesicles. In addition, LRP1 appears to have a role in the surface trafficking of $\operatorname{PrP}^{\mathrm{C}}$ (Parkyn et al., 2008). Dynamin I dominantnegative mutant K44A blocks both clathrin-mediated endocytosis and caveolae-mediated endocytosis (Henley et al., 1998; Nichols and Lippincott Schwartz, 2001; Conner and Schmid, 2003). We found that dynamin I K44A suppressed the endocytosis of both STI1 and PrP ${ }^{\mathrm{C}}$. Furthermore, the use of dynamin I K44A revealed that interaction of STI1 and $\mathrm{PrP}^{\mathrm{C}}$ at the cell surface has a transient nature, but inhibition of endocytosis allowed the identification of an intermediate step in which the two proteins appear to remain together.

A likely scenario to explain these results is that STI1 binds to $\mathrm{PrP}^{\mathrm{C}}$ at the cell surface and this triggers the interaction of the complex with unknown plasma membrane components that may mediate signaling by PKA. Simultaneously, $\mathrm{PrP}^{\mathrm{C}}$ endocytosis is triggered, and that may lead to a new set of interactions, perhaps involving LRP1 or other proteins that can help $\operatorname{PrP}^{\mathrm{C}}$ to piggyback to clathrin-coated vesicles, which may be important to cause ERK1/2 activation. Indeed, LRP1 has been shown to link cellular activation to ERK signaling (Orr et al., 2003) and is therefore a likely candidate to participate in this process for STI1$\operatorname{PrP}^{\mathrm{C}}$. Thereafter, STI1 and $\operatorname{PrP}^{\mathrm{C}}$ appear to follow parallel pathways downstream into the cells.

The physiological roles for STI1- $\operatorname{PrP}^{\mathrm{C}}$ signaling in vivo remain to be established (see (Linden et al., 2008). However, it is of remarkable interest that expression of truncated forms of $\operatorname{PrP}^{C}$ in a PrP-null background has been consistently shown to cause neurodegeneration in transgenic mice (Shmerling et al., 1998; Baumann et al., 2007; Li et al., 2007). This intriguing phenotype resembles some of the alterations in prion disorders and can be mitigated by expression of wild-type $\mathrm{PrP}^{\mathrm{C}}$ in transgenic mice (Shmerling et al., 1998; Baumann et al., 2007; Li et al., 2007). The binding site of STI1 onto $\operatorname{PrP}^{\mathrm{C}}$ (amino acids 113-128) (Zanata et al., 2002) is lacking in all truncated proteins that produce this phenotype (Shmerling et al., 1998; Baumann et al., 2007), including a recently described mouse line with a deletion in amino acids 105-125 of $\mathrm{PrP}^{\mathrm{C}}$ (Li et al., 2007). Future experiments should unravel whether the mechanisms described here for STI1mediated $\operatorname{PrP}^{\mathrm{C}}$ signaling contribute to such phenotypes.

\section{References}

Americo TA, Chiarini LB, Linden R (2007) Signaling induced by hop/STI-1 depends on endocytosis. Biochem Biophys Res Commun 358:620-625.

Barbosa Jr J, Ferreira LT, Martins-Silva C, Santos MS, Torres GE, Caron MG, Gomez MV, Ferguson SS, Prado MA, Prado VF (2002) Trafficking of the vesicular acetylcholine transporter in SN56 cells: a dynamin-sensitive step and interaction with the AP-2 adaptor complex. J Neurochem 82:1221-1228.

Baron GS, Magalhães AC, Prado MAM, Caughey B (2006) Mouse-adapted scrapie infection of SN56 cells: greater efficiency with microsomeassociated versus purified PrP-res. J Virol 80:2106-2117.

Baumann F, Tolnay M, Brabeck C, Pahnke J, Kloz U, Niemann HH, Heikenwalder M, Rulicke T, Burkle A, Aguzzi A (2007) Lethal recessive myelin toxicity of prion protein lacking its central domain. EMBO J 26:538-547.

Bucci C, Thomsen P, Nicoziani P, McCarthy J, van Deurs B (2000) Rab7: a key to lysosome biogenesis. Mol Biol Cell 11:467-480.

Bueler H, Fischer M, Lang Y, Bluethmann H, Lipp HP, DeArmond SJ, Prusiner SB, Aguet M, Weissmann C (1992) Normal development and behaviour of mice lacking the neuronal cell-surface PrP protein. Nature 356:577-582.

Caughey B, Baron GS (2006) Prions and their partners in crime. Nature 443:803-810.

Caughey B, Raymond GJ (1991) The Scrapie-associated form of Prp is made from a cell-surface precursor that is both protease-sensitive and phospholipase-sensitive. J Biol Chem 266:18217-18223.

Chiarini LB, Freitas AR, Zanata SM, Brentani RR, Martins VR, Linden R (2002) Cellular prion protein transduces neuroprotective signals. EMBO J 21:3317-3326.

Coitinho AS, Lopes MH, Hajj GN, Rossato JI, Freitas AR, Castro CC, Cammarota M, Brentani RR, Izquierdo I, Martins VR (2007) Short-term memory formation and long-term memory consolidation are enhanced by cellular prion association to stress-inducible protein 1 . Neurobiol Dis 26:282-290.

Conner SD, Schmid SL (2003) Regulated portals of entry into the cell. Nature 422:37-44.

Daaka Y, Luttrell LM, Ahn S, la Rocca GJ, Ferguson SS, Caron MG, Lefkowitz RJ (1998) Essential role for $G$ protein-coupled receptor endocytosis in the activation of mitogen-activated protein kinase. J Biol Chem 273:685-688.

Drake MT, Shenoy SK, Lefkowitz RJ (2006) Trafficking of G proteincoupled receptors. Circ Res 99:570-582.

Erlich RB, Kahn SA, Lima FR, Muras AG, Martins RA, Linden R, Chiarini LB, Martins VR, Moura Neto V (2007) STI1 promotes glioma proliferation through MAPK and PI3K pathways. Glia 55:1690-1698.

Eustace BK, Jay DG (2004) Extracellular roles for the molecular chaperone, hsp90. Cell Cycle 3:1098-1100.

Evdonin AL, Martynova MG, Bystrova OA, Guzhova IV, Margulis BA, Medvedeva ND (2006) The release of Hsp70 from A431 carcinoma cells is mediated by secretory-like granules. Eur J Cell Biol 85:443-455.

Fivaz M, Vilbois F, Thurnheer S, Pasquali C, Abrami L, Bickel PE, Parton RG, van der Goot FG (2002) Differential sorting and fate of endocytosed GPI-anchored proteins. EMBO J 21:3989-4000.

Gaidarov I, Santini F, Warren RA, Keen JH (1999) Spatial control of coatedpit dynamics in living cells. Nat Cell Biol 1:1-7.

Glebov OO, Bright NA, Nichols BJ (2006) Flotillin-1 defines a clathrinindependent endocytic pathway in mammalian cells. Nat Cell Biol 8:46-54.

Gonzalez-Gaitan M (2003) Signal dispersal and transduction through the endocytic pathway. Nat Rev Mol Cell Biol 4:213-224.

Guzhova I, Kislyakova K, Moskaliova O, Fridlanskaya I, Tytell M, Cheetham M, Margulis B (2001) In vitro studies show that Hsp70 can be released by glia and that exogenous Hsp70 can enhance neuronal stress tolerance. Brain Res 914:66-73.

Hammond DN, Lee HJ, Tonsgard JH, Wainer BH (1990) Development and characterization of clonal cell lines derived from septal cholinergic neurons. Brain Res 512:190-200. 
Harder T, Simons K (1997) Caveolae, DIGs, and the dynamics of sphingolipid-cholesterol microdomains. Curr Opin Cell Biol 9:534-542.

Henley JR, Krueger EW, Oswald BJ, McNiven MA (1998) Dynaminmediated internalization of caveolae. J Cell Biol 141:85-99.

Hernandez MP, Sullivan WP, Toft DO (2002) The assembly and intermolecular properties of the hsp70-Hop-hsp90 molecular chaperone complex. J Biol Chem 277:38294-38304.

Honore B, Leffers H, Madsen P, Rasmussen HH, Vandekerckhove J, Celis JE (1992) Molecular cloning and expression of a transformation-sensitive human protein containing the TPR motif and sharing identity to the stress-inducible yeast protein STI1. J Biol Chem 267:8485-8491.

Houenou LJ, Li L, Lei M, Kent CR, Tytell M (1996) Exogenous heat shock cognate protein Hsc 70 prevents axotomy-induced death of spinal sensory neurons. Cell Stress Chaperones 1:161-166.

Keller M, Ruegg A, Werner S, Beer HD (2008) Active caspase-1 is a regulator of unconventional protein secretion. Cell 132:818-831.

Lassle M, Blatch GL, Kundra V, Takatori T, Zetter BR (1997) Stressinducible, murine protein $\mathrm{mSTI1}$. Characterization of binding domains for heat shock proteins and in vitro phosphorylation by different kinases. J Biol Chem 272:1876-1884.

Lee KS, Magalhães AC, Zanata SM, Brentani RR, Martins VR, Prado MAM (2001) Internalization of mammalian fluorescent cellular prion protein and N-terminal deletion mutants in living cells. J Neurochem 79:79-87.

Lee KS, Raymond LD, Schoen B, Raymond GJ, Kett L, Moore RA, Johnson LM, Taubner L, Speare JO, Onwubiko HA, Baron GS, Caughey WS, Caughey B (2007) Hemin interactions and alterations of the subcellular localization of prion protein. J Biol Chem 282:36525-36533.

Lefkowitz RJ, Whalen EJ (2004) beta-arrestins: traffic cops of cell signaling. Curr Opin Cell Biol 16:162-168.

Li A, Christensen HM, Stewart LR, Roth KA, Chiesa R, Harris DA (2007) Neonatal lethality in transgenic mice expressing prion protein with a deletion of residues 105-125. EMBO J 26:548-558.

Lima FR, Arantes CP, Muras AG, Nomizo R, Brentani RR, Martins VR (2007) Cellular prion protein expression in astrocytes modulates neuronal survival and differentiation. J Neurochem 103:2164-2176.

Linden R, Martins VR, Prado MA, Cammarota M, Izquierdo I, Brentani RR (2008) Physiology of the prion protein. Physiol Rev 88:673-728.

Lopes MH, Hajj GN, Muras AG, Mancini GL, Castro RM, Ribeiro KC, Brentani RR, Linden R, Martins VR (2005) Interaction of cellular prion and stress-inducible protein 1 promotes neuritogenesis and neuroprotection by distinct signaling pathways. J Neurosci 25:11330-11339.

Luttrell LM, Ferguson SS, Daaka Y, Miller WE, Maudsley S, Della Rocca GJ, Lin F, Kawakatsu H, Owada K, Luttrell DK, Caron MG, Lefkowitz RJ (1999) Beta-arrestin-dependent formation of beta2 adrenergic receptorSrc protein kinase complexes. Science 283:655-661.

Magalhães AC, Silva JA, Lee KS, Martins VR, Prado VF, Ferguson SSG, Gomez MV, Brentani RR, Prado MAM (2002) Endocytic intermediates involved with the intracellular trafficking of a fluorescent cellular prion protein. J Biol Chem 277:33311-33318.

Magalhães AC, Baron GS, Lee KS, Steele-Mortimer O, Dorward D, Prado MA, Caughey B (2005) Uptake and neuritic transport of scrapie prion protein coincident with infection of neuronal cells. J Neurosci 25:5207-5216.

Manson JC, Clarke AR, Hooper ML, Aitchison L, McConnell I, Hope J (1994) 129/Ola mice carrying a null mutation in PrP that abolishes mRNA production are developmentally normal. Mol Neurobiol 8:121-127.

Martins VR, Linden R, Prado MAM, Walz R, Sakamoto AC, Izquierdo I, Brentani RR (2002) Cellular prion protein: on the road for functions. FEBS Lett 512:25-28.

Morris RJ, Parkyn CJ, Jen A (2006) Traffic of prion protein between different compartments on the neuronal surface, and the propagation of prion disease. FEBS Lett 580:5565-5571.

Mouillet-Richard S, Ermonval M, Chebassier C, Laplanche JL, Lehmann S, Launay JM, Kellermann O (2000) Signal transduction through prion protein. Science 289:1925-1928.

Nichols BJ, Lippincott-Schwartz J (2001) Endocytosis without clathrin coats. Trends Cell Biol 11:406-412.

Orr AW, Pedraza CE, Pallero MA, Elzie CA, Goicoechea S, Strickland DK, Murphy-Ullrich JE (2003) Low density lipoprotein receptor-related protein is a calreticulin coreceptor that signals focal adhesion disassembly. J Cell Biol 161:1179-1189.

Parkyn CJ, Vermeulen EG, Mootoosamy RC, Sunyach C, Jacobsen C, Oxvig C, Moestrup S, Liu Q, Bu G, Jen A, Morris RJ (2008) LRP1 controls biosynthetic and endocytic trafficking of neuronal prion protein. J Cell Sci 121:773-783.

Parsell DA, Lindquist S (1993) The function of heat-shock proteins in stress tolerance: degradation and reactivation of damaged proteins. Annu Rev Genet 27:437-496.

Peters PJ, Mironov Jr A, Peretz D, van Donselaar E, Leclerc E, Erpel S, DeArmond SJ, Burton DR, Williamson RA, Vey M, Prusiner SB (2003) Trafficking of prion proteins through a caveolae-mediated endosomal pathway. J Cell Biol 162:703-717.

Pimpinelli F, Lehmann S, Maridonneau-Parini I (2005) The scrapie prion protein is present in flotillin-1-positive vesicles in central- but not peripheral-derived neuronal cell lines. Eur J Neurosci 21:2063-2072.

Prusiner SB (1998) Prions. Proc Natl Acad Sci U S A 95:13363-13383.

Ribeiro FM, Black SA, Cregan SP, Prado VF, Prado MA, Rylett RJ, Ferguson SS (2005) Constitutive high-affinity choline transporter endocytosis is determined by a carboxyl-terminal tail dileucine motif. J Neurochem 94:86-96.

Robinson MB, Tidwell JL, Gould T, Taylor AR, Newbern JM, Graves J, Tytell M, Milligan CE (2005) Extracellular heat shock protein 70: a critical component for motoneuron survival. J Neurosci 25:9735-9745.

Samaia HB, Brentani RR (1998) Can loss-of-function prion-related diseases exist? Mol Psychiatry 3:196-197.

Santos MS, Barbosa Jr J, Veloso GS, Ribeiro F, Kushmerick C, Gomez MV, Ferguson SS, Prado VF, Prado MA (2001) Trafficking of green fluorescent protein-tagged vesicular acetylcholine transporter to varicosities in a cholinergic cell line. J Neurochem 78:1104-1113.

Santuccione A, Sytnyk V, Leshchyns'ka I, Schachner M (2005) Prion protein recruits its neuronal receptor NCAM to lipid rafts to activate p59fyn and to enhance neurite outgrowth. J Cell Biol 169:341-354.

Shmerling D, Hegyi I, Fischer M, Blattler T, Brandner S, Gotz J, Rulicke T, Flechsig E, Cozzio A, von Mering C, Hangartner C, Aguzzi A, Weissmann C (1998) Expression of amino-terminally truncated $\operatorname{PrP}$ in the mouse leading to ataxia and specific cerebellar lesions. Cell 93:203-214.

Shyng SL, Heuser JE, Harris DA (1994) A glycolipid-anchored prion protein is endocytosed via clathrin-coated pits. J Cell Biol 125:1239-1250.

Shyng SL, Moulder KL, Lesko A, Harris DA (1995) The N-terminal domain of a glycolipid-anchored prion protein is essential for its endocytosis via clathrin-coated pits. J Biol Chem 270:14793-14800.

Stuermer CA, Langhorst MF, Wiechers MF, Legler DF, Von Hanwehr SH, Guse AH, Plattner H (2004) PrPc capping in T cells promotes its association with the lipid raft proteins reggie-1 and reggie-2 and leads to signal transduction. FASEB J 18:1731-1733.

Sunyach C, Checler F (2005) Combined pharmacological, mutational and cell biology approaches indicate that p53-dependent caspase 3 activation triggered by cellular prion is dependent on its endocytosis. J Neurochem 92:1399-1407.

Sunyach C, Jen A, Deng J, Fitzgerald KT, Frobert Y, Grassi J, McCaffrey MW, Morris R (2003) The mechanism of internalization of glycosylphosphatidylinositol-anchored prion protein. EMBO J 22:3591-3601.

Taylor DR, Hooper NM (2006) The low-density lipoprotein receptorrelated protein 1 (LRP1) mediates the endocytosis of the cellular prion protein. Biochem J 402:17-23.

Taylor DR, Watt NT, Perera WS, Hooper NM (2005) Assigning functions to distinct regions of the $\mathrm{N}$-terminus of the prion protein that are involved in its copper-stimulated, clathrin-dependent endocytosis. J Cell Sci 118:5141-5153.

Tidwell JL, Houenou LJ, Tytell M (2004) Administration of Hsp70 in vivo inhibits motor and sensory neuron degeneration. Cell Stress Chaperones 9:88-98.

Vieira AV, Lamaze C, Schmid SL (1996) Control of EGF receptor signaling by clathrin-mediated endocytosis. Science 274:2086-2089.

Weissmann C (1999) Molecular genetics of transmissible spongiform encephalopathies. J Biol Chem 274:3-6.

Westergard L, Christensen HM, Harris DA (2007) The cellular prion protein $(\operatorname{PrP}(\mathrm{C}))$ : its physiological function and role in disease. Biochim Biophys Acta 1772:629-644.

Yu Q, Kent CR, Tytell M (2001) Retinal uptake of intravitreally injected Hsc/ Hsp70 and its effect on susceptibility to light damage. Mol Vis 7:48-56.

Zanata SM, Lopes MH, Mercadante AF, Hajj GN, Chiarini LB, Nomizo R, Freitas AR, Cabral AL, Lee KS, Juliano MA, de Oliveira E, Jachieri SG, Burlingame A, Huang L, Linden R, Brentani RR, Martins VR (2002) Stress-inducible protein 1 is a cell surface ligand for cellular prion that triggers neuroprotection. EMBO J 21:3307-3316. 